\title{
TRADYCJA JAKO ELEMENT BUDOWY TOŻSAMOŚCI. PRZYPADEK ŻOŁNIERZY ODDZIAŁÓW WOJSK SPECJALNYCH
}

\section{Jarosław Rybak*}

Abstrakt

Tradycje wojskowych formacji historycznych nadal służą jako czynnik ułatwiający budowanie tożsamości współczesnych żołnierzy. Tradycji nie należy jednak odnosić wyłącznie do historii. Można bez niej skutecznie budować tożsamość, opierając się na wartościach takich, jak elitarność czy wspólnota ekstremalnych przeżyć. Kluczową rolę może odgrywać także tradycja wytworzona, która przyspiesza i ułatwia budowę tożsamości grupy. Metodą indywidualnego wywiadu pogłębionego przebadano siedmiu żołnierzy: z okresu II wojny światowej, PRL-u oraz współczesnych (ekspertów z dużym doświadczeniem bojowym i dowódczym).

Słowa kluczowe: tradycja wojskowa, budowa tożsamości, żołnierze, komandosi, tożsamość w ponowoczesności, tradycja wytworzona, rytuały wojskowe, symbolika wojskowa, elitarność

\section{TRADITION AS AN ELEMENT OF IDENTITY BUILDING. THE CASE OF THE SPECIAL UNITS SOLDIERS}

\begin{abstract}
Modernity have any impact on military identity. It was proved that traditions of historical military formations serve as a factor that facilitates building identity of modern Special Forces soldiers. Referring to historical traditions gives them a sense of "nobility" and strengthen their "military backbone". Tradition, however, should not be perceived with regard to history only. It's possible to build identity effectively basing on values such as elitism or a community of extreme experiences. Invented tradition, which precipitates and facilitates building identity of the group, can also play a key role. The Individual In-depth Interview technique was used to examine seven soldiers of different generations. They served in the army during World War II, afterwards (over the communist period) and contemporarily. The last ones are experts with extensive combat and command experience.
\end{abstract}

Keywords: military tradition, identity building, soldiers, identity in postmodernity, invented tradition, military rituals, special forces symbols, elitism, extreme experiences

\footnotetext{
*Jarosław Rybak, badacz niezależny, Warszawa, Polska

e-mail: biuro@jaroslawrybak.pl | ORCID: http://orcid.org/0000-0003-1280-3647
} 
"Tradycja to dąb, który tysiąc lat rósł w górę. Niech nikt kiełka małego z dębem nie przymierza! Tradycja naszych dziejów jest warownym murem.

To jest właśnie kolęda, świąteczna wieczerza, to jest ludu śpiewanie, to jest ojców mowa, to jest nasza historia, której się nie zmieni"

Napis na wewnętrznych drzwiach sali tradycji Jednostki Wojskowej Komandosów w Lublińcu - cytat z wypowiedzi głównego bohatera filmu Miś (1980) w reżyserii Stanisława Barei.

\section{Wstęp}

We wszystkich państwach jednym z najbardziej elitarnych rodzajów wojsk są siły specjalne. W Polsce liczą one zaledwie niecałe 3\% stanu osobowego armii. Żołnierze Wojsk Specjalnych (WS) przygotowują się do wykonywania zadań na szczeblu operacyjnym i strategicznym, działają w niewielkich zespołach, najczęściej z dala od wojsk własnych, na tyłach przeciwnika. Krytycznie odpowiedzialne zadania, jakość wyposażenia i wyszkolenia, odporność na stres, determinacja w realizacji rozkazu, przekonania o słuszności działań własnych wymagają ludzi starannie wyselekcjonowanych, o cechach psychofizycznych dostosowanych do zadań. Należy domniemywać, że muszą posiadać silną tożsamość własną i poczuciejedności z grupą.

W artykule autor analizuje rolę, jaką w procesie budowy tożsamości żołnierzy oddziałówWS odgrywa tradycja. Autor ma świadomość, iż pomimo stosowania profesjonalnych metod i narzędzi, badanie opinii żołnierzy jest działaniem trudnym, zagrożonym dużym ryzykiem wyciągnięcia błędnych wniosków. Ścisła hierarchia, dostosowanie się do roli w grupie skutkuje tym, że żołnierze wpisują się w społeczne (wewnętrzne 
i zewnętrzne) oczekiwania. W odpowiedzi na nie mogą przyjmować odpowiednie role, dostosowując do nich wypowiadane opinie.

Autor zdecydował się jednak na taki temat, gdyż zna specyfikę tego środowiska. Od roku 1997 publikuje książki i artykuły prasowe o polskich siłach specjalnych. Przebywał na misjach w Kosowie, Macedonii, Bośni, Kuwejcie, Iraku, Afganistanie oraz Kongu. W roku 2004 został pierwszym dziennikarzem, któremu Kapituła ds. Odznaki GROM przyznała Honorową Odznakę J ednostki Specjalnej GROM¹. Siedem lat później otrzymał podobne wyróżnienie od żołnierzy J ednostki Wojskowej Komandosów z Lublińca. Pracując w Ministerstwie Obrony Narodowej i Biurze Bezpieczeństwa Narodowego zajmował się m.in. tematyką Wojsk Specjalnych oraz tradycji wojskowych.

Doświadczenie i posiadanie zaufania środowiska doprowadziło autora do próby przeprowadzenia badań socjologicznych. Główne pytanie badawcze brzmiało: jaką funkcję odgrywa tradycja w oddziałach WS?

Uszczegóławiając je, poddano analizie sześć następujących kwestii:

1. J aką wagę ma tradycja dla żołnierzy WS?

2. W jakim zakresie tradycja może być wykorzystywana do budowy tożsamości oddziałówWS?

3. J akie znaczenie ma tradycja dla oddziałów WS funkcjonujących w erze późnej nowoczesności?

4. J akie są możliwości budowania tożsamości oddziałów WS bez odwoływania się do tradycji?

5. J akie warunki należy spełnić, aby tradycję można wykorzystywać w procesach budowy (utrwalania) tożsamości oddziałów WS?

6. J aką rolę pełni tożsamość historyczna dla przebiegu służby żołnierzy WS?

Główna hipoteza zakładała zaś, że tradycje wojskowych formacji historycznych są czynnikiem ułatwiającym budowanie tożsamości współczesnych żołnierzy WS.

I Odznaka ma numer 35, co oznacza o znaczy, że wcześniej - w ciągu kilkunastu lat istnienia tego oddziału - w podobny sposób wyróżniono jedynie 34 osoby. 
Hipotezy szczegółowe zakładały, że:

1. Tradycja (na etapie planowania autor odnosił ją bezpośrednio do historii wojskowości) jest dla żołnierzy WS spoiwem, wokół którego budują tożsamość własną oraz własnych oddziałów.

2. Tradycja pozwala na emocjonalną łączność z poprzednimi pokoleniami żołnierzy, daje poczucie przynależności do elitarnej grupy i pozytywnie wpływa na postawę moralną, może być zatem wykorzystywana do budowy tożsamości oddziałów WS.

3. Pomimo głębokich przemian społecznych, będących efektem późnej nowoczesności, wojsko jest organizacją konserwatywną, dlatego nawiązywanie do tradycji nadal ma znaczenie dla oddziałów WS.

4. Wojskowe jednostki specjalne z lat 1951-1989 nie odnosiły się, lub odnosiły się w sposób mocno sformalizowany do tradycji, a mimo to posiadały mocną tożsamość, która przetrwała dekady po zakończeniu służby wojskowej. Można więc budować tożsamości oddziałów WS bez odwoływania się do tradycji.

5. Tradycje można wykorzystywać w procesach budowy (utrwalania) tożsamości oddziałów WS, ale muszą one być bliskie, atrakcyjne i zrozumiałe dla żołnierzy.

6. Tożsamość historyczna ma wpływ na przebieg służby, ponieważ daje dodatkową motywację, podnosi morale, ułatwia pokonywanie trudów szkolenia i działań bojowych, może wspomóc w sytuacjach trudnych (śmierć czy obrażenia towarzyszy broni).

W czasie badań autor szeroko przeanalizował kwestietradycji, tożsamości i dziedzictwa w nowoczesności i późnej nowoczesności. Skupił się na uproszczeniach w tradycji oraz tradycji wytworzonej.

Uproszczenia w tradycji

Tradycja, szczególnie zbiorowa, aby była uniwersalna, musi być zrozumiała i atrakcyjna dla członków zbiorowości. „Tradycja nie tylko upraszcza 
i ujednoznacznia przeszłość grupową, ale także wyróżnia nade wszystko te jej aspekty, które w świetle dostępnej wiedzy jawią się jako stosunkowo prostei jednoznaczne” (Szacki 1971: 274). Uproszczenia ułatwiają wskazywanie obszarów tematycznych „obowiązkowych” dla członka danej grupy. Od żołnierza nie trzeba więc wymagać szczegółowej znajomości przebiegu II wojny światowej, ale należy oczekiwać znajomości jej epizodów kształtujących tradycję narodu (Westerplatte, Bitwa o Anglię, Powstanie Warszawskie, Monte Cassino).

Uproszczeniom towarzyszy jednocześnie proces, który autor określa mianem „naskórkowości”. Polega on na często bardzo pobieżnej znajomości faktów, do których odnoszą się kontynuatorzy. J erzy Szacki opisuje ten problem w sposób następujący: „W procesie kształtowania tradycji wiedza o przeszłości nie stanowi instancji decydującej. Badaczowi tradycji grupowych kwestia wiedzy historycznej zarówno własnej, jaki grupy badanej, wydaje się kwestią drugoplanową. Przyjęcietradycji zależy bowiem raczej od wiary (...) aniżeli od wiedzy o tym, czy tak jest rzeczywiście i czy owe „tradycyjne” idei instytucje są dziś tym, czym były kiedyś (ibidem: 240).

Badacz powinien więc dokonać kluczowego założenia, że czym innym jest badanie tradycji społeczeństwa czy grupy społecznej, a czym innym zaś badanie ich znajomość przeszłości. Na to zaś należy nałożyć kontekst kulturowy, zależny od zmieniającej się rzeczywistości. Szacki podaje przykład noszenia męskiego nakrycia głowy zwanego konfederatką. Przez większą część XIX wieku tę charakterystyczną czapkę można traktować jako element dziedzictwa kulturowego jednej z warstw społecznych - szlachty. J ednak po roku 1864, czyli po upadku Powstania Styczniowego, konfederatka stała się elementem tożsamości grupy, jaka stanowili emigranci - powstańcy uciekający przez prześladowaniami carskimi (ibidem: 144).

Podobnie potraktować można buty tzn. oficerki (ze względu na wysoki połysk popularnie nazywane wtedy „szklankami”). Przed wybuchem II wojny światowej był to jeden z elementów umundurowania 
żołnierzy czy policjantów. W czasie okupacji hitlerowskiej „szklanki”, noszone przez młodych mężczyzn, oznaczały pozytywny stosunek do konspiracji.

Uproszczeniu ulegają role, jakimi obdarzamy osoby, symbole i rzeczy istotne dla tradycji indywidualnej czy zbiorowej. Dlatego dla zwolenników tradycji narodowej młodzi konspiratorzy z oddziałów specjalnych Armii Krajowej, wykonujący spektakularne wyroki śmierci na dygnitarzach niemieckich w okupowanej Warszawie, są przykładem poświęcenia własnego zdrowia i życia dla walki z okupantem. Niewielu zwolenników tej tezy zadaje sobie trud lektury dostępnych wspomnień konspiratorów, w których opisują oni przykłady niesubordynacji, łamania zasad konspiracyjnych, ostrych konfliktów wewnątrz oddziałów.

Działalności konspiracyjnej towarzyszył wszechobecny stres (Pawlina 2016: 122) wynikający ze stałego zagrożenia życia oraz okupacyjnej codzienności. Do tego czas wojny charakteryzował się olbrzymim rozwarstwieniem. Większość Polaków cierpiała głód. Przed rokiem 1939 przeciętna dzienna wartość spożycia wynosiła 2508 kalorii, natomiast w roku 1940 zmalała do 624 kalorii (ibidem: 74). Natomiast osoby zajmujące się szmuglem, handlem na czarnym rynku czy produkcją bimbru żyły zdecydowanie bardziej dostatnio. Choć było to niezgodne z podziemnym prawem i surowo karane przez podziemne sądy, to zajmowali się tym również żołnierze konspiracji. Znajdowali się oni w uprzywilejowanej pozycji, gdyż „legalnie” między siebie mogli dzielić część przedmiotów czy produktów zdobytych na Niemcach.

Część z żołnierzy podziemia mogła starać się o etat w organizacji. Oznaczał regularne pensje. Wypłacano je w Armii Krajowej, Gwardii Ludowej czy Milicji Ludowej (ibidem: 105). J ako ciekawostkę warto podać, że w Kedywie AK pensje zależały od zaszeregowania (podział na trzy grupy uzależnione od stopni wojskowych) i obszaru działania (np. w miastach wojewódzkich, dzielnicach z walutą niemiecką). Wypłacano również dodatek rodzinny. W drugiej połowie 1943 roku podstawowe uposażenie szeregowego konspiratora na etacie wynosiło 1700 zł, a na 
standardowe, miesięczne utrzymanie w Warszawie należało wydać 1500 zł. Kilka miesięcy później samodzielne utrzymanie pochłaniałojuż 2000 zł (ibidem: 112-113). Organizacja podziemna dysponowała również dodatkami specjalnymi (na utrzymanielokali konspiracyjnych, zapomogi dla rodzin poległych, przejazdy łączniczek, opał na zimę). „Etatowcy" byli elitą Kedywu, pozostali konspiratorzy mogli liczyć najwyżej na indywidualne, niewielki zapomogi.

Bieda i łatwy dostęp do broni prowadziły do przestępstw - rabunków. Państwo Podziemne ścigało przestępcóww swoich szeregach. Podziemne sądy nakładały na nich surowe kary łącznie z wyrokami śmierci (ibidem: 120).

Poprawie kondycji psychicznej i morale było odpowiednie dzielenie obowiązkami w konspiracji. W roku 1943 w Kedywie wprowadzono miesięczne urlopy wypoczynkowe dla żołnierzy (ibidem: 126). Sposobem radzenia sobie ze stresem było zaś zachowanie dystansu ${ }^{2}$ do rzeczywistości, powszechne spożywanie alkoholu (nadużywanie go było w podziemiu zabronione) oraz... posiadanie broni. To ostatnie dawało poczucie spokoju (ibidem: 328).

Na powyższych przykładach wyraźnie widać, że historyczna rzeczywistość mocno odbiega od współczesnego wyobrażenia o niej. Jerzy Szacki konstatuje: „W tradycji narodowej istnieje Kościuszko w Krakowie pod Racławicami i Maciejowicami, ale nie Kościuszko w Szwajcarii, Kołłątaj - autor Listów Anonima, ale nie targowiczanin, Mickiewicz romantyczny poeta i trybun, ale nie kochanek". Tradycja wymaga od nas konstruowania bohaterów-modeli o „brązowniczych wizerunkach” (Szacki 1971: 272).

Dodaje jednocześnie, że elementy dziedzictwa włączane do tradycji są idealizowane. „J edynieniepoprawnie naiwni racjonaliści mogą żądać

\footnotetext{
${ }^{2}$ Kwestia dystansu do otaczającej rzeczywistości pojawiała się w wielu rozmowach autora z żołnierzami. Wydaje się, że najlepszym tego przykładem jest (przywołany na początku artykułu) napis na drzwiach izby tradycji jednej z najbardziej elitarnych jednostek WP. Cytat jest głęboki w treści, ale pochodzi z kultowej komedii, która rozbawia już kolejne pokolenie Polaków. Można domniemywać, że wprowadza w zakłopotanie wielu oficjalnych gości zwiedzających to miejsce.
} 
od tradycji „,́́cisłości historycznej” w tym znaczeniu, by składające się na nią wzory były dokładnie takie, jak w przeszłości. Dla funkcjonowania w polskiej tradycji patriotyczno-religijnej hymnu „Boże cos Polskę” nic nie ma do rzeczy fakt, żeAlojzy Feliński napisał go na cześć Aleksandra I, chcąc upamiętnić rocznicę objęcia przezeń tronu Królestwa Polskiego" ibidem: 178).

Społeczne oczekiwanie „pomnikowych bohaterów” oraz jednoznacznie kwalifikowanych wydarzeń jest na tyle silne, że próby „odbrązowienia" narażają osoby podejmujące takie działania nierzadko na ostrą krytykę. Taki proces możemy zaobserwować przy próbach rzeczowej analizy zadań elitarnych oddziałów Armii Krajowej w czasie okupacji niemieckiej. Ich członkowie, walczący w ramach Kedywu, w oddziałach specjalnych AK czy Cichociemni, wykonywani operacje o charakterze specjalnym (np. eliminowali tzw. cele priorytetowe - wykonywali wyroki śmierci na wyselekcjonowanych przedstawicielach władz okupacyjnych). Osoby kierowane do tych zadań były specjalnie wyselekcjonowane, przeszkolone, funkcjonowały w sprawnym systemie dowodzenia oraz wsparcia - zapewnianego na miarę możliwości Państwa Podziemnego - socjalnego oraz medycznego.

J ednak w momencie wybuchu Powstania Warszawskiego ten system przestał funkcjonować. Ściśle zakonspirowane oddziały ujawniły się, rozbudowywano je w oparciu o lokalne zasoby - często nieprzygotowanych ochotników. Walki prowadzone przez doraźniestworzone struktury na terenie miasta były działaniami nieregularnymi, a nie specjalnymi.

Choć powyższe fakty znane są żołnierzom współczesnych oddziałów specjalnych, nie przeszkadza im to w budowaniu własnej tradycji oraz tożsamości, bardziej na epizodzie powstańczym, niż na odwoływaniu się do merytoryczniebliższych im działań, prowadzonych od 1940 do 1sierpnia 1944 roku.

Obawy dotyczące „odbrązowienia” i ucieczki przed wchodzeniem w szczegóły historyczne wydają się po części zrozumiałe. Szacki pisze bowiem, że w „odbrązowianiu” może chodzić o narzucenie innego mitu, 
o zmianę tradycji lub przekształcenie jej w antytradycję (ibidem: 272). Trudno się z taką argumentacją nie zgodzić.

Cenna jest konstatacja, iż naszą wiedzę, poglądy i postawy kształtują np. literackie dzieła Henryka Sienkiewicza i poematy Adama Mickiewicza, a nie prawda historyczna.

Tradycja wytworzona

Uproszczenia i idealizacja to nie wszystko, z czym musi się pogodzić badacz nadmiernie przywiązany do faktów z przeszłości. Naukowcy rozpoczęli badania tzw. tradycji wytworzonych. To elementy współtworzące tradycję, które uważamy za prawdziwe, ich wystąpienie w przeszłości mogło być prawdopodobne, ale w rzeczywistości są to odwołania do fikcji.

Warto w tym miejscu zatrzymać się nad fenomenem „Małego Powstańca”. To jeden z najbardziej rozpoznawalnych symboli Powstania Warszawskiego. Pomnik odsłonięty w roku 1983 przy murach Starego Miasta przedstawia kilkuletnie dziecko w niemieckim hełmie, panterce, z pistoletem maszynowym.

Rzeźba de facto zakłamuje historię. Nie tylko dlatego, że z braku broni żaden powstaniec nie oddałby kilkulatkowi pistoletu maszynowego. Chłopczyk z bronią jest bowiem zaprzeczeniem funkcji wychowawczej Szarych Szeregów. Dziecko w wieku „Małego Powstańca” nie mogło ani być członkiem formacji powstańczej, ani - tym bardziej walczyć. Pomnik był jednak bardzo ważny ideologicznie. Dla ówczesnej komunistycznej władzy był symbolem bohaterstwa dzieci - niewinnych ofiar Powstania Warszawskiego (Napiórkowski 2016: 177).

Wytworzenie powyższej tradycji dodatkowo ułatwił wiersz Stanisława R. Dobrowolskiego Warszawskie dzieci pójdziemy w bój, którego fragment znajduje się na tablicy umieszczonej przy pomniku. Melodia ułożona do słów tego wiersza stała się jednym z hymnów Powstania Warszawskiego, a spora część śpiewających, tekst traktuje dosłownie. 
J est to bowiem - wg Szackiego (1971: 144): „akt emocjonalnej identyfikacji ze swymi poprzednikami”.

Po tych kilku jednostkowych przykładach warto dłużej zatrzymać się nad wpływem Powstania na współczesne życie społeczno-polityczne. „Nie samo wydarzenie odgrywa główną rolę w dyskursie, ale siedem dekad politycznych, moralnych i estetycznych sporów. Współczesne odczytania Powstania nawiązują w mniejszym stopniu do tego, co działo się w roku 1944, w znacznie większym zaś do skomplikowanej historii pamięci" (Napiórkowski 2016: 8).

Na ten dyskurs ma wpływ nieprzepracowana żałoba z końca lat 40. $\mathrm{XX}$ wieku, przymusowe zapomnienie doby stalinizmu, opozycyjne demonstracje z lat 80., okres „zaniedbania pamięci” z lat 90. i „przegapionej” 50. rocznicy wybuchu. „Nasze dzisiejsze hołdy, nawiązania i spory nie odsyłają nigdy wprost do upamiętnianego wydarzenia, lecz zawsze wchodzą w skomplikowany dialog z tym, jak o powstaniu mówiło się, pisało czy milczało w poprzednich dekadach" (ibidem: 8).

Dyskusje mają czysto emocjonalne podłoże. To - transponowane na kolejne pokolenia Warszawiaków - wspomnienia pierwszych miesięcy i lat po roku 1945. Powracający do stolicy narażeni byli na widoki, przy których bledły przeżycia wcześniejszych pięciu lat okropieństw wojny. „To co po «wyzwoleniu» Warszawy ukazało się oczom powracających do niej mieszkańców i przybywającego wojska, przekraczało wszelkie dotychczasowe wyobrażenie. (...) Całkowite zrujnowanie miasta - zawalenie wszystkich jego budynków, zagruzowanie ulic, zniszczenie infrastruktury - okazało się tylko tłem dla prawdziwego horroru" (ibidem: 61-62). Były to dziesiątki tysięcy zwłok ofiar powstańczych walk.

Traumatyzujące doznania były rozłożone w czasie. Zimą 1945 roku zwłoki znajdowały się pod śniegiem, mróz wstrzymywał rozkład ciał. Na początku marca ukazało się rozporządzenie o tym, że w pierwszej kolejności należy grzebać zwłoki leżące na ulicach, podwórzach i klatkach schodowych (ibidem: 74). Leżały tam zwłoki noworodków czy ludzi potężnie okaleczonych za życia. Można było rozpoznać wiek, płeć, a nawet 
zidentyfikować ciała. W czasie walk bomby trafiały w prowizoryczne mogiły defragmentując zwłoki i rozrzucając szczątki na dużej powierzchni.

Olbrzymie ilości zwłok utrudniały szybką organizację pochówków. Dlatego we wrześniu 1945 roku, na polecenie władz Państwowego Zakładu Higieny, palono - niedopalone przez Niemców - zwłoki ofiar walk. Prace ekshumacyjne trwały do późnych lat 50. XX wieku.

Dochodziło do sytuacji - z dzisiejszej perspektywy - paradoksalnych. „Z opisywanych po latach relacji wynika, że radość z odnalezienia zwłok ukochanego syna czy towarzysza walki była czasem równie wzruszająca, jak spotkanie z żywym" (ibidem: 77). Nieobecność przy pochówku, brak ostatniego pożegnania ze zmarłym były dodatkowym źródłem traumy.

Efektem tych wszystkich makabrycznych doznań jest trauma przekazywana przez ówczesnych mieszkańców stolicy na kolejne pokolenia warszawiaków.

Na te masowe przypadki osobistego obcowania z niewyobrażalną tragedią nałożyła się polityka i ideologia. Prowadziła ona do „zawłaszczania ciał”, czyli kultu prawomyślnych bohaterów (bojowników Armii Ludowej), niewinnych ofiar (ludności cywilnej) i zawłaszczania pamięci dotyczącej przeciwników politycznych (Armii Krajowej) (ibidem: 88). Komunistyczna propaganda pokazywała mieszkańców Warszawy jako bohaterski lud, deprecjonując i wykluczając część zmarłych i żywych przeciwników władzy.

Po roku 2004 na mocno upolitycznioną pamięć o Powstaniu nałożyła się komercjalizacja. Zmienił się też sposób komunikacji. Popularnestały się powieści historyczne, polityczne science-fiction, komiksy, filmy montowane z materiałów archiwalnych i rekonstrukcji. W portalu Facebook stworzono profil, na którym fikcyjni uczestnicy Powstania relacjonują swoje 63 dni walk. „Miesza się fakty z fikcją i dokument z fabułą” (ibidem: 355), a „pamięć popularna miesza mit i historię” (ibidem: 360). W jednym tyglu zmiksowano profesjonalne podejście naukowcówi amatorskie, zaangażowane emocjonalnie, podejście pasjonatów historii. 
Historia Powstania ma oddziaływać na wyobraźnię. Stąd popularność wycieczek w miejsca zachowanych pamiątek (np. ze śladami krwi powstańców, pozostałości po ostrzałach), gry terenowe, umożliwiające „podróż w czasie”, czy zwiedzanie silnie oddziaływującego na emocje Muzeum Powstania Warszawskiego.

J uż kilka tych wybiórczych przykładów pokazuje, jak wiele wspólnego ma tradycja Powstania Warszawskiego z „tradycją wynajdywaną”. Problem tej ostatniej omawiają różni naukowcy, których teksty zebrali Eric Hobsbawm i Terence Ranger w publikacji Tradycja wynaleziona (2008). Poprzez analogię z omawianymi tam przykładami, autor pracy założył, iż „wynajdywanie tradycji” może odgrywać istotną rolę w funkcjonowaniu Wojsk Specjalnych.

Takie tradycje dotyczą obrzędów przejścia (inicjacji, awansu, przejścia w stan spoczynku, śmierci) (Hobsbawm 2008: 18). Charakterystyczny dla nich jest również „znamienny zestaw atrybutów” (Roper 2008: 25), to stroje, używane przedmioty, ceremonialność. Wytwarzaniu tradycji sprzyja rozwój ceremonializmu (Cannadine 2008: 140). Wszystko to zaś ma służyć „umacnianiu i legitymizowaniu instytucji, pozycji bądź relacji władzy” (Hobsbawm 2008: 17). Przykłady potwierdzające powyższe tezy zauważymy we wszystkich oddziałach WS.

Hobsbawm uważa tė̇, iż znaczna część procesu tworzenia tradycji nie została wyjaśniona, ale: „Najbardziej wyrazistą postać przybiera on tam, gdzie «tradycja» jest z rozmysłem wynaleziona i zaprojektowana przez pojedynczego autora” (ibidem: 12). Działania takie już w momencie inicjowania nazywane są „tradycyjnymi”. Tak było w roku 1932, gdy w BBC król J erzy V wygłosił przemówienie bożonarodzeniowe - od razu uznano je za tradycyjne (Cannadine 2008: 142). Te przykłady pomagają wyjaśnić fenomen tworzenia wizerunku jednostki GROM.

W niektórych przypadkach tradycja wytworzona może stać się uciążliwa dla samych jej wytwórców. Budując legendę jednostki specjalnej GROM, twórcy formacji, mocno wdrukowali w świadomość społeczną 
mity, które możemy określić mianem tejże tradycji. Dotyczyły one wyimaginowanych zdolności i osiągnięć bojowych do jakich doszło w pierwszej dekadzie istnienia oddziału. Gdy zaś w drugiej dekadzie żołnierze rozpoczęli realne działania bojowe w Iraku czy Afganistanie, tradycja wytworzona przyćmiewała faktyczne osiągnięcia.

Na koniec rozważań o tradycji wynalezionej wspomnieć należy, że hasło opisujące podstawowe wartości żołnierskie: „Bóg - Honor - Ojczyzna” jest przejawem tego typu tradycji. Od odzyskania niepodległości do wybuchu II wojny światowej dewizą Wojska Polskiego był „Honor i Ojczyzna”. „Boga” dodano oficjalnie w roku 1943, a następnie przywrócono w III RP. Była to kontra do wartości promowanych w ramach indoktrynacji komunistycznej w czasach Ludowego Wojska Polskiego (LWP).

Wychowawcza funkcja tradycji

W tradycji możemy szukać elementów pomocnych wychowywaniu członków danej grupy czy społeczności. Aby osiągnąć ten cel, tradycje należy upowszechniać. „Polega to nade wszystko na propagowaniu pewnych wartości i wzorów do naśladowania. Uznanie jakiejś tradycji za dobrą zależy od orzeczenia o jej aktualnej funkcji wychowawczej" (Szacki 1971: 152).

Dlatego od początku roku 2000 możemy obserwować intensywne prace nad wyrazistym wpisaniem Powstania Warszawskiego w czołówkę kanonu tradycji narodowych. Oficjalny przekaz wykorzystywany w tym celu jest prosty i jednoznaczny. Przedstawia powstańców jako młodych ludzi, którzy ponad wszystko umiłowali wolność ojczyzny, ruszyli do walki choć ich siły były skrajnie nieproporcjonalne w porównaniu z potencjałem Niemców. Zostali następnie zdradzeni, gdyż przywódcy sowieccy wstrzymali ofensywę i pozwolili się Warszawie wykrwawić. Ten przekaz okazał się bardzo atrakcyjny. Skutkowało to popularyzacją uroczystości rocznicowych czy przejmowaniem tradycji oddziałów powstańczych przez współczesne jednostki Wojska Polskiego (WP). 
W ostatnich latach podobne metody zastosowano przy wprowadzeniu do świadomości społecznej terminu „Żołnierzy Wyklętych”. W wybranych grupach społecznych, do których instytucje państwowe i publiczne kierowały przekaz, osiągnięto efekt podobny. Choć ze względu na kontrowersje dotyczące działania Żołnierzy Wyklętych, nie był on już tak jednoznaczny i powszechny, jak w przypadku powstańców warszawskich.

Niezależnie od tego czy neguje, czy afirmuje tradycję, żaden zaangażowany członek zbiorowości nie może być wobec niej obojętny. Musi się do niej odnieść. Dlatego należy domniemywać, iż w przypadku żołnierza presja otoczenia wymusza na nim pozytywne odniesienie się do tradycji wojskowej.

Tradycja w późnej nowoczesności

Wybranym grupom społecznym tradycja ułatwia odnalezienie się w świecie. J est to szczególnie istotne w postnowoczesności, w której zmiany społeczne zdecydowanie przyspieszyły, utraciły ciągłość, a poglądy zradykalizowały się. Nie wiadomo, co należy myśleć na dany temat, jak się zachowywać w błyskawicznie zmieniającym się świecie. Powoduje to problemy z umiejscowieniem jednostki czy grupy w szerszej strukturze.

W takich sytuacjach pomocne bywa odniesienie się do wzorców określonych w tradycji. Ułatwia ona życie, pozwala odnaleźć się w rzeczywistości. Wydaje się, iż w przypadku żołnierzy ułatwia odpowiedzi na istotne pytania, które stale towarzyszą im podczas służby. J aki jest sens ryzykowania życia w czasie misji w Iraku (jeśli zewsząd docierają głosy o braku uzasadnienia inwazji koalicji międzynarodowej na to państwo) czy Afganistanie (w którym trzeba walczyć z talibami, a być może nie są to terroryści, ale bojownicy kierujący się podobnymi wartościami, jak żołnierze Armii Krajowej z czasów II wojny światowej)?

Późna nowoczesność zmienia istotnie relacje w rodzinie, która coraz bardziej przestaje mieć model patriarchalny, z ojcem jako jej „głową”. 
Mamy również do czynienia z kryzysem klasycznej męskości. Tymczasem w tych właśnie dziedzinach konserwatywne struktury społeczne, do jakich zaliczamy wojsko, nadal hołdują wartościom tradycyjnym.

Wojsko to środowisko, w którym cytując fragment piosenki Alicji Majewskiej - „Męska rzecz być daleko, a kobiety - wiernie czekać”, to obszar zarezerwowany dla „silnych mężczyzn”. Nadal są obszary niedostępne dla kobiet (pododdziały bojowe jednostek specjalnych, załogi okrętów podwodnych). Takie podejście to trend nie tylko polski, jest typowy dla nowoczesnych armii większości państw.

Tradycja w Siłach Zbrojnych RP

Współcześnie w Siłach Zbrojnych RP (SZ) przejmowanie tradycji odbywa się na podstawie decyzji nr 229 ministra obrony narodowej z roku 2004. Warunkiem dziedziczenia tradycji jest związek danej jednostki wojskowej z jednostką, której tradycje mają być dziedziczone, wynikający z:

a) tożsamości lub powinowactwa rodzaju Sił Zbrojnych,

b) tożsamości numeru lub nazwy,

c) wspólnoty regionu stacjonowania lub formowania.

J ednostce wojskowej, a w uzasadnionych przypadkach pododdziałowi, może być nadane imię osoby szczególnie zasłużonej dla SZ i obronności państwa oraz zajmującej poczesne miejsce w tradycji narodu i oręża polskiego.

Decyzje o przejęciu tradycji i nadania imienia patrona inicjuje kadra jednostki wojskowej. Działania prowadzone w jednostce wojskowej wymagają uzgodnienia z departamentem ministerstwa obrony narodowej (MON), odpowiedzialnym za sprawy tradycji. Zgodnie z procedurą ostateczną decyzję o nadaniu jednostce dziedzictwa tradycji (po zasięgnięciu m.in. opinii Komisji Historycznej MON do Spraw Symboliki Wojskowej i Tradycji) podejmuje minister obrony narodowej. 
Teoretycznie więc wojsko przykłada dużą wagę do tradycji. Należy jednak zadać pytanie czy jej rola została faktycznie zauważona i doceniona przez samych żołnierzy oraz teoretyków i praktyków wojskowości? Można bowiem domniemywać, że właściwe wykorzystanie dziedziczonych tradycji wojskowych (ustalonych rytuałów, praktyk materialnych, jak i niematerialnych, przekazu symbolicznego: wartości, mitów, idei) powinno mieć duży wpływ na funkcjonowanie praktycznie każdego oddziału wojskowego (od etapu naboru kandydatów, przez pracę z żołnierzami w służbie czynnej, do budowania więzi z weteranami i kombatantami). Na etapie planowania pracy, autor założył, że świadomość dziedziczonych tradycji ułatwia budowę tożsamości indywidualnej i zespołowej żołnierzy.

Wydaje się, iż będzie to szczególnie łatwe do zaobserwowania - choć ze względu na specyfikę bardzo trudne do rzetelnego zbadania - wjednostkach specjalnych. Te bowiem, ze względu na wielowymiarową elitarność poszukują kandydatów do służby o ściśle określonych, ponadprzeciętnych cechach etyczno-moralnych i psycho-fizycznych.

\section{Badania społeczne żołnierzy}

Systematyczne badania społecznew Siłach Zbrojnych prowadzone są przez wyspecjalizowaną, zatrudniającą kilkunastu pracowników, komórkę organizacyjną MON, jaką jest Wojskowe Biuro Badań Społecznych (WBBS.)

Badania takie mogą również prowadzić osoby lub podmioty zewnętrzne. Badaczy obowiązuje przestrzeganie decyzji ministra obrony narodowej w sprawie prowadzenia badań społecznych w resorcie obrony narodowej. Prowadzenie badań wymaga uzyskania zgody. Następuje to po dogłębnej analizie tematu, celu i techniki badań, wskazaniu jednostek wojskowych do przeprowadzenia badań, określeniu wielkości próby oraz grup żołnierzy typowanych do badania. W przypadku prac dyplomowych opiniujący musi również znać informacje o promotorze pracy, otrzymać 
pisemne zgody dowódców jednostek wojskowych, w których badania mają być przeprowadzone.

Pracownicy WBBS prowadzą systematyczne badania zbieżne z tematyką niniejszego artykułu. Wynika z nich, iż żołnierze zawodowi posiadają świadomość znaczenia wiedzy historycznej dla pełnienia służby wojskowej, są pozytywnie nastawieni do tradycji wojskowych oraz prezentują właściwe postawy patriotyczne i obywatelskie w życiu zawodowym oraz społecznym.

Badacze z WBBS konstatują, iż: „Żołnierze zawodowi mają świadomość znaczenia wiedzy historycznej dla pełnienia służby wojskowej, są pozytywnie nastawienie do tradycji wojskowych oraz prezentują właściwe postawy patriotyczne i obywatelskie w życiu zawodowym i społecznym. (...) Zdaniem większości badanych wiedza historyczna, zwłaszcza dotycząca tradycji oręża polskiego ma duży wpływ na ma kształtowanie się patriotyzmu. Tworzy poczucie dumy z przynależności do Sił Zbrojnych RP oraz wzmacnia morale” (Zauer 2018: 4-5)

Warto zaznaczyć, iż prace WBBS odbywają się według wszelkich zasad prowadzenia badań socjologicznych. J ednak - w opinii autora - należy zakładać, iż nie oddają one w pełni opinii badanych. Na poprawność prowadzenia badań należy bowiem nałożyć - niemierzalne i nieformalne zasady kultury organizacyjnej wojska. Od chwili założenia munduru żołnierzjest szkolony do wykonywania rozkazów przelożonych oraz pozytywnego reagowania na domniemane oczekiwania przelożonych.

Posiadając zasób wiedzy, wynikający z wieloletnich obserwacji oraz pracy z żołnierzami, autor założyl, iż respondenci WBBS zawyżali wskaźniki, które uznawali za oczekiwane przez przelożonych i otoczenie.

Respondenci badani w ramach pracy

W trakcie planowania pracy autor wytypował kilkanaście osób, które miały wziąć udział w badaniach. Ich celem było poznanie opinii eksperckich żołnierzy mających duże doświadczenie bojowe, dowódcze, 
angażujących się w działania związane z tworzeniem tożsamości oddziału i kultywowaniem tradycji. Ostatecznie przeprowadzono siedem wywiadów. Respondenci zostali zanonimizowani, byli przedstawicielami trzech pokoleń żołnierzy: z czasów II wojny światowej, okresu PRL-u oraz współczesnych.

Wywiady pogłębione prowadzono na podstawie kwestionariusza. Poniżej przedstawiam krótkie opisy respondentów, wraz z zasygnalizowanie ich motywacji wejścia do struktur wojskowych.

1. Halina Jedrzejewska ps. „Sławka” (ur. 1926). Pochodzenie inteligenckie, bez związków rodzinnych z wojskiem, wykształcenie wyższe. W konspiracji od lipca 1940 roku do października 1944 (w batalionie „Miotła”). Walczyła w Powstaniu Warszawskim. Po wojnie ukończyła studia medyczne. Dwukrotnie odznaczona Krzyżem Walecznych. Do konspiracji poszła, „bo szli wszyscy”.

2. Respondent W2 (ur. 1950 r.), pochodzenie robotniczochłopskie, bez związków rodzinnych z wojskiem, wykształcenie wyższe. Podpułkownik w stanie spoczynku, 20 lat służby wjednostkach specjalnych Ludowego Wojska Polskiego. Najwyższe stanowisko: szef sztabu 1. Batalionu Szturmowego. Po zakończeniu służby pedagog i działacz społeczny aktywnie angażujący się w promocję polskich oddziałów specjalnych. Do jednostki specjalnej został skierowany przez przełożonych.

3. Respondent W3 (ur. 1967 r.), pochodzenie chłopskie, bez związków rodzinnych z wojskiem, wykształcenie wyższe. Podpułkownik rezerwy, 15 lat służby w jednostkach specjalnych, uczestnik misji wojskowych na Haiti, Bałkanach, w Iraku i Zatoce Perskiej. W Iraku dowódca zespołu bojowego, który tuż przed inwazją sił międzynarodowych wykonał zadanie przejęcia kontroli nad terminalem przeladunkowym ropy naftowej w porcie Umm Kasr, co otworzyło dostęp siłom koalicyjnym do jedynego pelnomorskiego portu w Iraku. Do jednostki specjalnej 
trafil przez przypadek: „Będąc w szkole oficerskiej, na czwartym roku kierowali nas na półroczne praktyki. Trafiłem 12. Dywizji Zmechanizowanej do Szczecina. Tam przejrzałem na oczy, jaki w wojsku jest syf i burdel. Pomyślałem, że zdechnę w takim wojsku, to był dla mnie motywator. Byłem zdesperowany. Moim celem było nie trafić do jednostki zmechanizowanej, każda inna była dobra. Nie wiedziałem, co to jest GROM, ale to nie były «zmechole», do tego Warszawa, a nie jakiś Żagań. Wszedłem jak w dym".

4. Respondent W4 (ur. 1973 r.), pochodzenie robotnicze, bez związków rodzinnych z wojskiem, wykształcenie wyższe. Pułkownik, 27 lat służby, w tym 20 w Wojskach Specjalnych. Przez kilka lat dowodził Zespołem Bojowym, uczestnik misji w Iraku i Afganistanie. Służbę wjednostce specjalnej wybrał, ponieważ „była atrakcyjna”.

5. Respondent W5 (ur. 1975 r.), pochodzenie robotnicze, bez związków rodzinnych z wojskiem, wykształcenie wyższe. Podpułkownik, 25 lat służby w jednostkach specjalnych, uczestnik misji wojskowych na Bałkanach, w Iraku, Afganistanie. Najwyższe stanowisko - dowódca Zespołu Bojowego. Służbę wjednostce specjalnej wybrał „ze względu na elitarność, na te zadania, które się tutaj robi. Niewiele osób było w stanie spełnić wymogi, żeby tu wejść, dostęp do «zabawek» niedostępnych w innych jednostkach. To dawało poczucie wyjątkowości, a nie bycia częścią masy. To była chęć utożsamienia się z elitarną grupą. Na tamtym etapie tradycje nie były dla mnie ważne.

6. Respondent W6 (ur. 1979 r.), pochodzenie robotnicze, bez związków rodzinnych z wojskiem, wykształcenie średnie. Chorąży rezerwy, 18 lat służby wjednostce specjalnej. Uczestnik misji na Bałkanach, w Iraku i Afganistanie. Powody wyboru służby w jednostce specjalnej tłumaczy następująco: „Przez przypadek, 
ale właściwie dzięki ojcu, bo już nie mogłem z nim wytrzymać. Poszedłem do WKU i powiedziałem «weźcie mnie do wojska, bo ojca zabiję». Tak się zaczęła moja przygoda.

7. Respondent $\mathbf{W}_{7}$ (ur. 1982 r.), pochodzenie chłopsko-robotnicze, wykształcenie wyższe. Chorąży rezerwy, 17 lat służby w jednostce specjalnej. Uczestnik misji na Bałkanach, w Iraku i Afganistanie, dwukrotnie ranny w czasie akcji bojowej. Przez 10 lat członek - powoływanej przez Prezydenta RP - kapituły Orderu Krzyża Wojskowego (współczesnego odpowiednika Orderu Virtuti Militari). Służbę w jednostce specjalnej wybrał, ponieważ: „Chciałem być zajebisty. Dziadek był «Strzelcem». To miało wpływ na świadomość mojego ojca, a ojciec modelował mnie. J ako młody człowiek wstąpiłem do «Strzelca»«. Do zasadniczej służby wojskowej trafiłem dojednostki specjalnej i tam zostałem".

Analizując wypowiedzi warto zauważyć, że (w odróżnieniu od wielu ankietowanych przez WBBS), żaden z respondentów nie uważał, iż w wyższym stopniu od otoczenia interesował się historią wojskowości. Deklarowali natomiast dobrą znajomość dziedziczonych tradycji, zainteresowanie współczesną geopolityką i sytuacją bezpieczeństwa w Polsce i na świecie. Swój status społeczny, definiowany jako wypadkową dochodu i stylu życia, oceniali jako ponadprzeciętny.

Wszyscy z dystansem podeszli do pytań dotyczących poglądów społecznych i politycznych oraz wpisania ich w działania obecnych partii i ruchów politycznych. W4 stwierdził: „Niejestem prawicowcem i lewicowcem, nie toleruję ruchów nacjonalistycznych, tak samo jak wpychania się LGBT do przestrzeni publicznej. Nienawidzę skrajności, więc raczej jestem centrum, ale nie do końca”. W6 swoje poglądy zdefiniował następująco: „Kiedyś oglądałem TVN, potem TVP. Teraz nic nie oglądam. Konserwatywne mam jakieś poglądy, siłą rzeczy prawa strona, bo na pewno nie lewa. Choć znam żołnierzy, którym bliżej do lewicy”. Do częściowo lewicowych poglądów przyznał się W2: „Liberalne w zakresie 
gospodarki jak i nadbudowy. W sprawach religii, szkoły, relacji międzyludzkich - liberalne z lewicowym podejściem do polityki społecznej”. Natomiast W7 to „Wyznawca teorii prawicowych, nie skrajnych, ale opartych na haśle «Bóg - Honor - Ojczyzna». Nikt mi nie powie, że teraz ma być tęczowo. My musimy kultywować te nasze konserwatywne tradycje. I ja taki jestem”. W5 określił się jako: „Środek, ale skażony konserwatyzmem".

Analiza wyników badania

Na podstawie przeprowadzonych wywiadów pogłębionych oraz ponad 20-letniej obserwacji (często obserwacji uczestniczącej), autor wytypował osiem obszarów mogących mieć kluczowe znaczenie dla budowy tożsamości żołnierzy oddziałów specjalnych.

Wskazującje, badani podkreślali zarówno ich aspekty teoretyczne, jak i praktyczne. Celem głównym było doprowadzenie do sytuacji, w której żołnierz w jak największym stopniu utożsami się z zespołem, co ułatwi wykonywania zadań służbowych. Kolejne części artykułu omawiają wskazane obszary kluczowe.

Wspólnota wyznawanych wartości

Każda armia na świecie jest organizacją o strukturze hierarchicznej, z jasnym podziałem kompetencji, przywilejów i obowiązków. „Armia jest jedną z wielu organizacji istniejących w życiu społecznym. Występują w niej liczne cechy, które spotykamy również w innych organizacjach, ale w stopniu częstokroć spotęgowanym" (Wiatr 1983: 28).

Od jej członków wymaga się ścisłego podporządkowaniai bezwzględnego wykonywania rozkazów. Dlatego przeważa w niej więź formalna nad personalną, jest biurokratyczna, ma strukturę ściśle hierarchiczną, o jasno określonych zasadach awansu, z podporządkowaniem wyłącznie 
pionowym (góra - dół). J est środowiskiem społecznym o własnym systemie uwarstwienia. Wiatr uważa, że armia jest też grupą bojową, zorganizowaną do zwycięskiej walki: „To co wyróżnia armię jako instytucję swoistą, to szczególne nasilenie tych cech" (ibidem: 29).

Z tych powodów jest to również instytucja o charakterze konserwatywnym, nie akceptująca odchyleń od norm obowiązujących w tej społeczności. Aby jej członkowie mogli prawidłowo funkcjonować w takiej grupie, muszą kierować się podobnymi wartościami. We współczesnej Polsce zdefiniowano je hasłem „Bóg - Honor - Ojczyzna”.

Odwołując się do doświadczeni z misji w Iraku i Afganistanu oraz kilkuletniej służby wśród żołnierzy amerykańskich, jeden z respondentów stwierdzil:

„Myślę, że kierunek jaki został obrany jakiś czas temu jest dobry. Przede wszystkim chodzi o kwestie związane z naszą ojczyzną, honorem, historią i tradycjami. Ważny jest też wątek religijny, powinien być zachowany, bo to jest częścią naszej tradycji. Niektórym się może wydawać, że ten element Boga nie jest potrzebny, ale to ich sprawa. To ułatwia pokonanie ciężkich sytuacji, nie widziałem na wojnie niewierzących żołnierzy" (W7).

Wszyscy respondenci zgadzali się, że wojsko jest przesiąknięte tradycjami, wchodząc w to środowisko jednostka musi się w tradycyjne wartości wkomponować. J eden z nich tłumaczył to następująco:

„W wojsku na całym świecie ważne są: mundur, odznaki stopni, odznaczenia, sposób oddawania honorów. To wynika z tradycji i historii. Stając się żołnierzem wchodzisz w system. J eśli go nie zaakceptujesz, system cię wypchnie” (W5).

Dowódca różnych szczebli wskazywał:

„J eśli chcemy zbudować dobry zespół, to on musi mieć tożsamość i tradycję.J eżeli tego nie zrobimy, zbudujemy zespół, który rozleci się, gdy zabraknie przywództwa. Tojest jak z Attylą, opanował pół świata, a po jego śmierci imperium się rozpadło. J eśli budujemy zespół na silnym przywództwie, gdy nie ma innych elementów, to członkowie zespołu będą czekać aż dowódca im powie co robić” (W4). 
Respondent, który przez kilkanaścielat był żołnierzem sekcji specjalnej, przekonywał, że silne utożsamienie z grupą przekłada się na większe, fizyczne bezpieczeństwo tej grupy:

„Bez tego w czasie operacji nie wejdzie się do budynku. Nie zrobisz tego zludźmi, których nie znasz. Ja miałem ten komfort, że pracowałem w grupie, w której każdy się znał, wiedział czego od siebie i innych oczekiwać" (W6).

Samo wejście w środowisko nie przekłada się automatycznie na przejęcie wartości istotnych w tym środowisku. Temu służy praca z nowicjuszami. Cały cykl szkoleniowy oparty jest na tym, żeby adeptowi przekazywać system wartości. Uczestnik 18-miesięcznego, zaawansowanego kursu dla paramedyków amerykańskich sił specjalnych, stwierdził:

„Już na początku podstawowego kursu w amerykańskim żołnierzu buduje się system wartości poprzez pranie mózgu. Każdy rozpoczyna zajęcia recytując swój Soldier's Creed i tym kończy zajęcia. Maszerując, biegnąc śpiewa to swoje credo. Mamy więc połączenie treningu fizycznego i mentalnego. Myślę, że w Polsce by się to przyjęło. Dzięki temu mielibyśmy lepszych żołnierzy, a potem lepszych liderów. Naszym liderom, a mam okazję pracować ze słuchaczami Akademii Wojsk Lądowych [uczelni kształcącej oficerów wojska - J.R.], więc wiem, że wielu z nich brakuje «zęba». To dlatego, że nie mają liderów, którzy tego «zęba» potrafiliby zbudować na początku drogi wojskowej" (W7).

Wspólnotę wartości należy budować na wielu poziomach.

„Budowę tożsamości zacząć należy od szczebla podstawowego, jakim jest pojedynczy wojownik. Trzeba zacząć do systemu modelowania, czyli prania mózgu. Taki system działa w USA, Rosji, Chinach - wszędzie tam, gdzie są silne sily zbrojne" (W7).

Najsilniejsza tożsamość powinna charakteryzować najmniejszy pododdział zdolny do wykonywania zadań w terenie.

„Chodzi o to, że żołnierze idący razem na operację specjalną, muszą mieć pelne zaufanie do siebie nawzajem" (W2).

Kolejny respondent uważał, że - w odróżnieniu od konieczności „schodzenia” przy budowie tożsamości - tradycje powinno dziedziczyć się na poziomie jednostki wojskowej, a niejej pododdziałów, gdyż: 
„To buduje później pewną niepotrzebną rywalizację. Nie ma poczucia wspólnoty, gdy się spotykamy przy jednym stole, bo każdy ma swoją tradycję. Co prawda mamy wspólny znak jednostki, ale każdy zespół uwypukla swoją tradycję i swój własny znak" (W4).

J eden z respondentów wskazał na przemianę pokoleniową, która zmienia priorytety u młodych ludzi. To w dłuższej perspektywie wymusi zmiany nawet w bardzo konserwatywnych organizacjach, do jakich zaliczyć można wojsko:

„Terazjest totalnieinaczej, niż za czasów naszej młodości. Niektórzy młodzi szacunek do tradycji mogli wynieść z domu. Pozostałym, myślę że większości, totalnie to wisi. Oni przyszli dojednostki może dla przygody, na pewno dla pieniędzy, bo w tej chwili pieniądze są cholernie ważne, może dla wcześniejszej emerytury, może żeby pojeździć po świecie. Chyba takie motywacje wygrywają z naszymi wartościami" (W3) ${ }^{3}$.

\section{Bliskość wzorca}

Tożsamość należy budować na wartościach bliskich i atrakcyjnych dla jednostki oraz grupy. J eden z respondentów omówił to na przykładzie przejmowania tradycji przez oddziały Wojsk Obrony Terytorialnej na Śląsku:

„Chciano je budować na bazie AK [Armii Krajowej - J .R.], a to na Śląsku akurat bardzo nie działa. Natomiast o Powstaniach Śląskich cały czas się mówi. (...) J ak się ludziom z centrum Górnego Śląska opowiada, że Tadeusz Puszczyński wysadzał mosty tu i tu, to słyszysz: «Przecież ja tam mieszkam. Znam ten wiadukt! Ale jak te chłopaki tam podeszli, skoro tam teren jest odkryty?». Odpowiednio

\footnotetext{
30 kwestię wagi tradycji i historii zapytałem byłą szefową zespołu psychoterapeutów zajmujących się żołnierzami hospitalizowanymi z powodu stresu pourazowego w Klinice Psychiatrii, Stresu Bojowego i Psychotraumatologii Wojskowego Instytutu Medycznego (najbardziej renomowany w Polsce ośrodek leczenia takich zaburzeń, w którym leczono zdecydowaną większość żołnierzy uskarżających się na stres postraumatyczny). Przywołała zaledwie dwa - na kilkaset - przypadki pacjentów, którzy w czasie terapii, opisując powody wstąpienia do wojska, odwołali się do tradycji i historii. W4 skomentował to następująco: „Może właśnie dlatego tych kilkuset wylądowało w klinice, bo nie mieli odpowiedniej podbudowy?".
} 
dobrane tradycje są spoiwem. J eśli źle to zrobimy, to skończy się na pustym gadaniu" (W4).

W tym miejscu warto ponownie odnieść się do historii. Wyjaśnia ona masowość podziemnej AK (na terenach okupowanej Polski) oraz brak problemu z naborem ochotników do Wojska Polskiego (w państwach, w których tworzono polskie formacje zbrojne). Jest to bowiem efekt wcześniejszych działań związanych z promocją wartości niepodległościowych.

W okresie II Rzeczypospolitej jednym z fundamentów kształtujących tożsamość i tradycje wojska, wykorzystywanym również w edukacji i wychowaniu młodego pokolenia Polaków, był mit Powstania Styczniowego z roku 1863. Był to bowiem jeden z nielicznych zrywów, który nie budził kontrowersji społecznych i jednoczył Polaków. „Żyli jeszcze uczestnicy, a było na tyle odległe że nie dzieliło społeczeństwa i historyków, a co najwyżej historyków" (Markert 2004: 57). W odróżnieniu od powstańców, bohaterowie walk z czasów I wojny światowej, walk o odzyskanie niepodległości czy wojny polsko-bolszewickiej z roku 1920 pozostawali zawodowo i politycznie aktywni, dlatego łatwiej było odnosić się do wzorców ludzi z czasów odleglejszych, jeszcze żyjących, alejuż w większości przypadków wyłączonych z życia publicznego.

Autorem tej koncepcji był Józef Piłsudski. Konsekwentnymi, rozłożonymi w czasie działaniami dążył do tego, aby jego działalność była postrzegana jako kontynuacja walk z lat 1831 i 1863 oraz, żeby jego podkomendni czuli się spadkobiercami powstańców, a pielęgnowanie tradycji stało się elementem wychowania patriotycznego młodzieży (ibidem: 18).

J uż w czasie I wojny światowej Legioniści i działacze Polskiej Organizacji Wojskowej dbali o mogiły powstańcze i opiekowali się żyjącymi powstańcami. W kilka miesięcy po odzyskaniu niepodległości, w styczniu 1919 roku Piłsudski wydał pierwszy rozkaz dotyczący powstańcówuznał ich za żołnierzy WP, wojskowi i urzędnicy ministerialni mieli obowiązek oddawania honorów weteranom. Wtedy też restytuowano 
order Virtuti Militari - najwyższe odznaczenie za żołnierskie męstwo w czasie walki. Stało się to w rocznicę wybuchu Powstania Styczniowego (ibidem: 30).

18 grudnia 1919 roku uchwalono ustawę o przyznaniu stopni i praw oficerskich weteranom walk powstańczych z lat 1831, 1848 i 1863. Każdy niekarany weteran otrzymał honorowy, pierwszy stopień oficerski. Oficerowie awansowali zaś o stopień wyżej. Wszystkim żyjącym oraz wdowom po powstańcach przyznano dożywotnią pensję.

Wsparcie państwa uzupełniano wsparciem społecznym. W okresie II RP powstawały liczne stowarzyszenia pomocy weteranom walk powstańczych, finansowano domy weterana, tworzono kwatery powstańcze na cmentarzach. Najbardziej okazałą była (i jest do dziś) kwatera na warszawskim cmentarzu wojskowym na Powązkach. Powstańców zapraszano na uroczystości państwowe, religijne, patriotyczne, spotkania w szkołach. Chodzili na nie w specjalnych „przepięknych jednakowych mundurach" (ibidem: 58). 22 stycznia 1933 roku, w 70. rocznicę wybuchu Powstania Styczniowego i 250. rocznicę Odsieczy Wiedeńskiej, wWarszawie zorganizowano wielkie uroczystości pod patronatem prezydenta Ignacego Mościckiego oraz marszałka Józefa Piłsudskiego. Zgromadziły one kilkanaście tysięcy ludzi.

W 75. rocznicę zrywu żyło zaledwie 53 weteranów. 23 z nich przyjechało do Warszawy. Zamieszkali w luksusowych apartamentach Hotelu Europejskiego, a ich pobyt ufundował zarząd hotelu. Wszystkich weteranów odznaczono Orderami Odrodzenia Polski. Tym, którzy nie mogli dotrzeć do stolicy dostarczono paczki z upominkami.

W drugiej połowie lat 30. zaczęto nadawać patronaty (nazywane utedy „honorowymi szefostwami”) pułkom WP. Imiona i symbolikę powstańczą przyjęło wtedy pięć oddziałów.

Na powyższych przykładach widać, jak odrodzone państwo budowało swoją tożsamość na tradycjach zrywów powstańczych. Co warte podkreślenia, zdecydowana większość badanych żołnierzy, respondentów mojego badania, uważała, że w czasie II Rzeczypospolitej tradycje 
kształtowano nie tylko poprzez wychowanie w szkole i w organizacjach proobronnych. Równie ważną rolę przypisywali rodzinie. Natomiast Halina J ędrzejowska mówiła: „J a nie pamiętam żadnej sytuacji, w której by nam rodzice mówili o patriotyzmie. To było tak oczywiste, że nie trzeba było mówić”.

J eden z respondentów tak opisywał bezpośrednich kontakty młodych żołnierzy z weteranami II wojny światowej, podczas spotkania żołnierzy z J ednostki Wojskowej GROM z Cichociemnymi:

„Nie można było znaleźć lepszej grupy, żeby pokazać nam, na czym polega motywacja. Dla mnie było tego nawet za dużo. Tego patriotyzmu, że my to wszystko dla Polski robimy. To mnie dziwiło, zastanawiałem się, czy to jest prawdziwe, autentyczne? J ak wracałem do domu, to sam siebie pytałem, czy można było być aż tak zmotywowanym, tak nafaszerowanym tymi wartościami?" (W3).

Ponieważ wzorce powinny być bliskie, należy pracować z młodymi żołnierzami, którzy trafiają do zespołu. Przechodzą oni kilkuetapowy proces selekcji, więc wszyscy mają podstawowe informacje o tradycjach dziedziczonych przez oddział (jest to sprawdzane w ramach selekcji). Natomiast pierwszym okresie pobytu w zespole bojowym ta wiedza powinna zostać ugruntowana.

„Po to były tradycyjne spotkania z kombatantami, żeby tych młodziaków zabrać, żeby mogli sobie porozmawiać z kombatantami. Żeby takiemu pokazać miejsce w szyku, żeby sobie uświadomil, jak to jest" (W4).

Inny respondent zwrócił konieczność zachowania proporcji w sprawach idei i codziennego szkolenia:

„Z zainteresowaniem u kolegów było różnie. Nawet jak pojawiali się Cichociemni, to niektórzy mówili: «Dobra, to było dawno, mnie to nie interesuje». Ale byli tacy, nawet za bardzo zakręceni na ich punkcie. To pochłaniało dużo czasu, trzeba było dużo czytać, organizować spotkania. To nawet trochę przeszkadzało w normalnej pracy" (W3).

Kolejny zwrócił uwagę na inne zagrożenie. Zbyt ścisłe odwoływanie się do tradycji historycznej może stanowić pułapkę. Grupy konspiracyjne AK były oddziałami partyzantki miejskiej, Powstańcy Warszawscy nie 
mieli nic wspólnego z działaniami specjalnymi - a ich tradycje dziedziczą jednostki specjalne. Dlatego:

„Zespół Bojowy dziedziczący tradycje Commando ma de facto tradycje oddziału lekkiej piechoty szturmowej ukierunkowanej na działanie na styku wody i lądu. To nie jest specjalizacja tego zespołu. Gdyby teraz to tworzyli od zera, to popatrzyliby na swoje zadania i historię, to pewno wzięliby za patronów Samodzielną Kompanię Grenadierów. Ale mają inne tradycje i o nie muszą dbać" (W5).

Tradycja zawsze musi być żywa i atrakcyjna dla odbiorcy. Nie musi jednak odnosić się do historii. Bohaterem może być starszy kolega z zespołu, który jest mistrzem w swojej profesji.

„Symbol «Miotły» jest spoiwem historii z teraźniejszością. Ale żywsze jest wspomnienie starszego kolegi, niż czasów II wojny światowej. Odwiedzając zespół - już jako były dowódca - widzę, że oni budują sobie tradycje tego, co było 10 lat temu. Chłopaki pamiętają o protoplastach $\mathrm{z}$ «Miotty», ale z drugiej strony wspominają żołnierzy, którzy już odeszli do cywila: „A ten to był kozak - chciałbym być taki jak on. Ten był zajebistym snajperem - w Afganistanie każdy chciał z nim iść na robotę". To działa też w drugą stronę. Miałem świetnego minera «Cabiego», jak on szkolił innych minerów to opowiadał o rozmowach z «Miotlarzami», jak oni robili materiały wybuchowe w czasie wojny. Mówil: «żeby wam się nie wydawało, że to takie niesamowite, to powiem wam, że w Powstaniu Warszawskim już to wykorzystywano, a myśmy to tylko rozbudowali». To są takiełączniki” (W4).

Tożsamość oddziału można również budować na naśladowaniu oddziałów o podobnym przeznaczeniu, które już posiadają ugruntowana opinię. Tak zrobił Sławomir Petelicki, wskazując żołnierzom GROM-u przykłady brytyjskiej jednostki SAS, amerykańskiej Delta (w drugiej dekadzie istnienia GROM-u, gdy w mediach częściej mówiono o Navy SEALs, niż o Delcie - odwoływał się do Navy SEALs), rzadziej niemieckiej GSG-9, a nawet japońskich wojowników ninja.

„Gdybym był dowódcą, nie mając tradycji, zrobiłbym wszystko, żeby pokazać jakieś wzorce. Bardzo ważne jest wyznaczanie celów, wokół realizacji których się konsolidujemy. Nie jakichś wielkich, kosmicznych, ale kolejnych kroków które razem robimy, pokonujemy kolejne bariery. To integruje" (W3). 
Warto wyjaśnić jedną kwestię. Skoro GROM odwoływał się do elitarnych jednostek amerykańskich i brytyjskich, to do jakich wartości odwoływały się tejednostki? Zdaniem respondenta:

„Oni opierają się przede wszystkim na zadaniach. J eśli jestem żołnierzem takiej jednostki, to moja tożsamość wynika z zadań, jakie jednostka wykonuje. I ja te zadania będę wykonywał na najwyższym poziomie. «Seale» odwołują się czę́́ciowo do II wojny światowej, kiedy powstali. Ale przede wszystkim do wojny w Wietnamie, bo tam pierwszy raz w dużej skali prowadzili zadania, do jakich zostali powołani. «Delciaki» odwołują się do pierwszych lat istnienia i pierwszych, spektakularnych operacji. To ciekawy przykład, bo w USA działały inne jednostki, mające te same zadania, były dużo lepiej przygotowane. Ale zjakichś powodów Delta była bardziej dostrzeżona i mocniej promowana w mediach. «Zielone Berety» odwołują się do lat 50., kiedy te oddziały powstawały. Ale najbliższa jest im tradycja Wietnamu. Odwołują się do działań niekonwencjonalnych i do współdziałania z siłami lokalnymi - czyli wsparcia militarnego. Natomiast brytyjski SAS odnosi się do swoich początków w czasie II wojny. Co ciekawe, do tej pory potrafią planować i realizować operacje opierając się na długich rajdach na pojazdach. Mówię to całkiem poważne! Uczestniczyłem w takich planowaniach! Dziwiłem się czemu tak, przecież to dziś jest mało funkcjonalne, mamy śmigłowce. Ale oni lubią pojazdy terenowe i ileś dni zasuwania po pustkowiach. To ich silna tradycja jeszcze z II wojny" (W5).

\section{Jednoznaczność przekazu}

Specyfika służby wojskowej powoduje, że żołnierze (zarówno indywidualnie, jak i zbiorowo) oczekują prostych, jednoznacznych komunikatów. Ułatwia im to bowiem zrozumienie rozkazu (celu zadania i oczekiwań dowódcy) oraz pomaga eliminować dylematy moralne. Należy domniemywać, że podobnej jednoznaczności oczekują w kwestiach związanych z dziedziczeniem tradycji. J eden z badanych tak to wyjaśniał:

„Żołnierz, który dziedziczy tradycje musi mieć świadomość, że w tych tradycjach nie ma żadnej skazy. Tam nie może być pola manewru, żeby ktoś wepchnął 
szpilkę i powiedział: «A ci wasi patroni wcale nie byli tacy fajni. Bo coś tam robili złego». Tu powinna być zachowana pełna spójność. Dlatego dla mnie niejednoznacznymi patronami byliby Żołnierze Wyklęci. To tłumaczy, dlaczego w Lublińcu żołnierze woleli «Miotłę», a nie PSBS [Polski Samodzielny Batalion Specjalny - J.R.]" (W4).

Wszyscy badani podkreślali, że decyzje o dziedziczeniu tradycji mają wymiar polityczny i są pochodną budowy kanonu najważniejszych wartości, które ksztaltuje władza państwowa.

„Po zmianie systemu było kilka fal wzmożenia dotyczącego tradycji wojskowych. Zjednej strony odrzucono większość, jak nie wszystko, co wiązało się z tradycjami wojska formowanego nad Oką. Ale z drugiej, oficerowie wychowawczy w jednostkach, i ci zajmujący się tradycjami w MON wyrządzili wielu oddziałom wojskowym niedźwiedzią przysługę, zmuszając je do dziedziczenia określonych tradycji tylko z powodu tego, żejednostki miały podobne numery wyróżniające. 2 Korpus Zmechanizowany przejął tradycje 2. Korpusu Polskiego i wszystkich jednostek mających «2» w nazwie" (W2).

„Mam poglądy prawicowe, ale nie podoba mi się takie wymazywanie fragmentów historii, nawet jak się z tymi elementami historii nie utożsamiam. Idąc tym tropem, być może za 20 lat zamiast kontynuować tradycje batalionu «Parasol» będziemy kontynuować tradycje batalionu «Tęcza», bo do władzy dojdą ludzie maszerujący dziś z tęczowymi flagami? To powinno być apolityczne, choć z drugiej strony tradycje to określone wartości, a te wiążą się z polityką. Do tego wojsko opiera się na rozkazach, skoro podjęto decyzje o tradycjach, to tak ma być. I trudno ztym dyskutować" (W7).

Respondenci przekonywali, że nie należy zwlekać z nadawaniem tradycji nowopowstałym oddziałom wojskowym.

„Należy to robić szybko, bo to integruje. J eśli nie będzie to koordynowane «z góry», to pojawią się inicjatywy oddolne, od żołnierzy. J eden pododdział weźmie sobie takie tradycje, drugi inne, nie będzie spójności. Dużą rolę powinien odgrywać departament w MON, który zajmuje się tradycjami. To tam powinno być to koordynowane, ustawiane w logiczną całość” (W4). 
Badani widzą też zagrożenia dla spójnej tradycji i tożsamości. Wynikają one z kilku powodów: aktualnej „mody” (przed kilkunastoma laty - na tradycje skupione wokół oddziałów Polski Walczącej, przed kilkoma laty - na tradycje Żołnierzy Wyklętych), chęci przypodobania się decydentom politycznym, braku wiedzy historycznej u osób formalnie odpowiedzialnych za kwestie tradycji oraz żołnierzy podejmujących nieformalne inicjatywy oddolne.

„Osoby, które powinny modelować ten system mogą być niekompetentne, nie rozumieć tego wszystkiego, a zajmować się tradycjami tylko dlatego, że są na takim etacie. Możemy mieć starszego podoficera, który nie czuje pewnych wartości, ale awansował bo ma odpowiedni stopień i ileś lat służby. Albo w sekcji wychowawczej znajdą się ludzie, którzy się na tym nie znają, nie czują" (W7).

Najbardziej profesjonalnie kwestie tradycji i - wynikającej zniej - identyfikacji wizualnej opracowano i wdrożono w jednostce GROM. J ednak przed około dekadą żołnierze służący na misji wAfganistanie „oddolnie” wprowadzili nowy znak - białą „kotwicę” Polski Walczącej na kwadratowym czarnym tle. Ówczesny dowódca GROM-u, wyjaśniał autorowi pracy, że była to inicjatywa żołnierzy, którzy chcieli w ten sposób uczcić Powstańców Warszawskich, ale ostatecznie zakazał noszenia takich oznaczeń na mundurach.

„Petelicki na początku to wszystko uporządkował. Wydawaliśmy własne pieniądze, żeby kupić «Gromika» [Odznaka GROM-u - J.R.] w kolorach pustynnych i nosić w Iraku czy Afganistanie. Ale przyszła moda na «Kotwicę» i młodsi koledzy zaczęli z nią chodzić. J eśli już chcieli się odnosić do Powstania Warszawskiego, to mogli do Cichociemnych biorących w nim udział. Mieliśmy tradycje 316 Cichociemnych i rozmywaliśmy ją tysiącami powstańców” (W3).

„J ak to świadczy o dziedziczonych tradycjach? J ak się z nimi identyfikowali żołnierze, skoro nie chcieli nosić swojego znaku?" (W4).

Brakuje konsekwencji i spójności w nadawaniu oddziałom imion i przekazywaniu tradycji. Dowodzi tego błąd logiczny i brak wiedzy historycznej osób, które nadawały jednostce specjalnej z Gliwic tradycje wojennego oddziału „Agat”. Faktycznie bowiem „Agat” to ta sama jednostka 
co „Parasol” (którego tradycje dziedziczy J ednostka Wojskowa Komandosów - JWK). Był to zespół tych samych żołnierzy, z tym samym dowództwem i zadaniami. Nazwę oddziału i pseudonimy żołnierzy zmieniono wyłącznie z powodów konspiracyjnych.

„Kto ma przyjechać na rocznicę akcji na Kutscherę? Ekipa z Lublińca czy z Gliwic? To ważne dla współczesnych żołnierzy, ale również dla patronów. Żeby oni się nie pogubili. Patron to bardzo poważna decyzja, nie może dochodzić do takich rzeczy" (W3).

W połowie 2019 roku prochy Ryszarda Białousa, dowódcy batalionu Zośka (tradycje batalionu dziedziczy J WK) sprowadzono z Australii w asyście honorowej żołnierzy Wojsk Obrony Terytorialnej (WOT), których dowództwo odwołuje się do tradycji Komendy Głównej AK.

„Agat też «skacze po różnych tradycjach». Dziedziczy tradycje konspiracyjnej jednostki z Warszawy, ale jeden zjego zespołów przejął tradycje grupy «Wawelberga», walczącej w III powstaniu śląskim. Nazwa pochodzi od pseudonimu dowódcy tej grupy, kpt. Tadeusza Puszczyńskiego. Aleimię Puszczyńskiego nosi 13. Brygada WOT z Katowic. Teraz już tak naprawdę nikt nie wie, kto jest czyim spadkobiercom. Wchodzimy sobie w paradę" (W4).

J eden z badanych nazwał to „błędami w sztuce, które nigdy nie powinny się zdarzyć” (W2).

\section{Elitarność grupy}

Przynależność do najmniejszego rodzaju Sił Zbrojnych, któremu powierzono wykonywanie zadań o znaczeniu strategicznym lub operacyjnym, dysponującemu wyposażeniem i uzbrojeniem niedostępnym w innych rodzajach SZ, powoduje elitarność. Może to mieć bardzo istotny wpływ na szybką budowę silnego poczucia tożsamości członków tej społeczności.

„Podam przykład z ćwiczenia pewnej jednostki. Zamiast,, po postawieniu zadania zająć się planowaniem, tam mówią: «Dostaliśmy ważne zadanie, nikt w Polsce nie jest tak dobry, żeby to zadanie wykonać. Tylko my to mogliśmy dostać, 
tylko my je wykonamy€. Słuchałem tego ze zdziwieniem, ale to jest przykład budowy tożsamości. Tak można stworzyć spójny, mocno skonsolidowany zespół. Wtedy odwołanie do historii nie jest potrzebne" (W5).

„Tuż przed wybuchem wojny w Iraku przyjechał do campu pułkownik H. [dowódca zgrupowania amerykańskich sił specjalnych - J.R.] Taką mowę walnął, że Amerykanie byli zachwyceni. Mówił, że walczą o wolny świat, że tylko oni są w stanie pokonać Husajna. Oni stuchali, klepali się po plecach, byli napaleni na walkę. A ja sobie pomyślałem: «J a pierdzielę, to jest jak na szkoleniu politycznym w naszej szkole oficerskiej». Byłem zdziwiony, a nawet przerażony. Szczypałem się czy ja naprawdę jestem na wojnie? Ale potem już Amerykanów nie trzeba było motywować. Dostali swoją dawkę adrenaliny" (W3).

Z wojennych wspomnień Cichociemnych i żołnierzy kompanii Commando wynika, iż poczucie elitarności (i wynikające z niego poczucie większej - niż u żołnierzy jednostek regularnych - bezkarności) było najważniejszym elementem budowy tożsamości grupy.

Komandosi nosili berety zgodnie z brytyjskim, a nie polskim regulaminem (orzelek znajdował się nie na środku głowy, ale nad prawym okiem), siadając na krześle zdejmowali pasy, przewieszając je przez oparcie (to również było sprzeczne z polskim regulaminem). Przełożeni przymykali oczy na wszczynanie bójek z miejscową ludnością. Z powodu specyfiki szkolenia, trzymali się głównie we własnym gronie, dystansując od żołnierzy zjednostek regularnych.

Podobne „przywileje” mieli żołnierze jednostek specjalnych LWP. Ich wspomnienia przesycone są opowieściami o bójkach z cywilami, ucieczkach przed interweniującą milicją i Wojskową Służbą Wewnętrzną. W trakcie ćwiczeń z kradli inwentarz domowy. W podobny sposób pozyskiwali ubiór cywilny czy środki transportu.

W2, oficer, który służbę wojskową odbył w czasach PRL-u, stwierdził, że tradycja i tożsamość jednostek specjalnych z czasów LWP wynikała z poczucia silnego związku z „matką, czyli 6. Dywizją Powietrzno-Desantową, z której wyszły naszejednostki”. Takie samo wrażenie odnosili respondenci służący w wojsku po przemianach ustrojowych. 
„Wydaje mi się, że oni w Dziwnowie [Garnizonie stacjonowania 1. Batalionu Szturmowego - J.R.] byli bardziej przywiązywali do koloru beretu, do spadochroniarzy, niż do tradycji PSBS. Budowali tożsamość na elitarności. Kiedyś każdy skoczek spadochronowy to był komandos" (W6).

„W Lublińcu służyłem z ludźmi z 62. Kompanii, 56. Kompanii i 1. Batalionie Szturmowym. Oni byli przywiązani do tradycji swoich jednostek i trzymali się razem. Nawet podziały się robiły. Wiadomo było, że ten przyszedł z Bolesławca, a ten z Dziwnowa. Do historii się nie odnosili, ale mieli duże poczucie dumy ze służby w poprzednich jednostkach" (W4).

Inny badany tak wspominał służbę w pierwszych latach istnienia GROM-u:

„U nas ta elitarność zeszła bardzo nisko. Każdy zespół uważał się za najlepszy, a w nim jedna sekcja uważała się za lepszą od drugiej. Logistyka uważała, żejest ważniejsza od «szturmu», a «szturm», żejest ważniejszy od logistyki. Rywalizacja jest dobra, ale nie może się wymknąć spod kontroli. Żeby nie było skakania sobie do gardel" (W3).

Kolejny respondent wyraził opinie, która możestanowić podsumowanie powyższego wątku:

„Elitarność buduje silne poczucie tożsamości. Tylko jest bardzo cienka granica, żeby nie popaść w zajebistość. Bardzo łatwo wpaść w samozachwyt: «J estem taki, że nikt mi nie podskoczy». Dlatego, jeśli mamy silną tożsamość, to znajomość tradycji pozwala nam na zachowanie dystansu. Można powiedzieć: «Ej chłopie, jesteś taki zajebisty, ale przed tobą byli już tacy, którzy robili to wcześniej. Pracuj nad sobą»" (W4).

\section{Wspólnota ekstremalnych przeżyć}

Szybkiej budowie silnej tożsamości żołnierzy oddziałów specjalnych sprzyja wspólnota ekstremalnych przeżyć: sytuacje zagrożenia życia i zdrowia, wspólna walka, silny stres, świadomość, że można liczyć na pomocinnych. Kluczowym wydaje się świadomość zagrożenia życiai zdrowia połączona z silną motywacją oraz poczuciem misji i wspólnego celu. 
Dlatego silny zespół łatwiej zbudować wśród żołnierzy wysyłanych na wojnę czy strażaków z sekcji bojowych, niż wśród górników. Najprawdopodobniej trudno będzie stworzyć zespół o silnej tożsamości w środowisku himalaistów - w którym występują ekstremalne zagrożenia, ale cel nastawiony jest zwykle na sukces indywidualny, a nie grupowy.

Ekstremalne przeżycia połączone ze wspólnym celem potrafią przełamywać bariery, które w innych sytuacjach byłyby ciężkie do pokonania. J eden z respondentów podał przykład swojej ostatniej misji wAfganistanie:

„Na ostatnią operację myśmy pojechali w sześciu, a Afgańczyków było ze 40. Nie znaliśmy się z miejscowymi. J a się bardziej martwiłem o nas samych, a nie o całą operację. W Szaranie było inaczej, bo z PRC byliśmy codziennie [W czasie poprzedniej misji respondent stacjonował w bazie w Szaranie, gdzie szkolił siły antyterrorystyczne Provincial Response Company (PRC) - J.R.], jeździliśmy na wspólne roboty, poznaliśmy ich, od pewnego momentu witaliśmy „na misia”, byliśmy z nimi po imieniu. No i na dobówkę [Operacja trwająca 24 godz. - J.R.] można było z nimi polecieć, spokojnie spać w terenie. Wiedziałeś, że oni są w porządku" (W6).

Działania w trudnych warunkach nie tylko integrują, ale również sprawdzają jakość zespołu.

„Miałem okazję pracować dla korporacji. Przychodził prezes i mówil: «J esteśmy zespołem». Gówno prawda! Nie byliśmy żadnym zespołem. J emu się tylko tak wydawało. Siła zespołu wychodzi, gdy są sytuacje krytyczne, wtedy się okazuje czy jest zespół i jaki on jest. Kryzys to kluczowy moment, który wszystko weryfikuje" (W3).

Trudne warunki: długotrwały wysiłek fizyczny i działanie pod presją (czasu, dowódcy) zawsze były nieodłącznym elementem szkolenia. To pozwoliło na zbudowanie zespołów o silnej tożsamości w jednostkach specjalnych z czasów PRL-u, choć żołnierze działali wyłącznie w warunkach poligonowych, w których zdarzały się wypadki śmiertelne, ale nie było zagrożeń wojennych. Niektóre z nich przetrwały lata po rozwiązaniu jednostki. 
Za oczywistość można przyjąć stwierdzenie, że „najlepszym” katalizatorem osiągnięcia powyższych celów będzie udział w wojnie. W tym kontekście warto przeanalizować wypowiedzi Haliny J ędrzejewskiej:

„J a myślę, że nikt z nas nie chciał umierać, to jest jasne. Wie pan czym myśmy się martwili? J a pamiętam te rozmowy z moimi koleżankami. Żeby nie dopuścić do aresztowania, a jeśli nas zaaresztują, to my powinniśmy się zabić. Żadna z nas nie wiedziała, jaką ma odporność na ból, czy wytrzymamy śledztwo na gestapo. To była odpowiedzialność za rodzinę i kolegów z konspiracji”.

Lektura literatury wspomnieniowej z czasów II wojny światowej dostarcza przykładów poświęcenia własnego życia w celu ratowania towarzyszy broni. Podawała je również Halina Jędrzejewska. Wspominała ciężko rannych, którzy nie pozwalali, aby - jako sanitariuszka - udzielała im pomocy, gdyż uważali, że wcześniej takiej pomocy należy udzielić innym rannym kolegom.

Mówiła, że z żołnierzami „Miotły” „zaprzyjaźniła się na śmierć i życie”. Wyjaśniała jednocześnie, że to nie był duży zespół, nie cały oddział, ale około dziesięciu osób, które w czasie walk powstańczych wspólnie znalazły się w ekstremalnie trudnych sytuacjach. Należy więc domniemywać, że wojna przyspiesza integrację żołnierzy, ale silniei szybko oddziałuje na niewielkie zespoły, których żołnierze mają ze sobą bezpośredni kontakt i wspólnie wykonują zadania bojowe.

„Nasza grupka była w kilku sytuacjach niezwykle dramatycznych, niezwykle niebezpiecznych. Wtedy każdy chciał ratować tego drugiego. U «J ana Bożego» [Reduta i szpital powstańczy -J.R.]. Sytuacja była niezwykle trudna. (...) J ak już było pewne, że nikt nam z pomocą nie przyjdzie, że jak Niemcy wejdą, to nie możemy dopuścić, że ktokolwiek wpadł wich ręce. Myśmy się umówili, kto kogo, po kolei, zabije. To była taka odpowiedzialność za grupę".

Czy silne relacje można zbudować w sytuacjach, które nie niosą ze sobą zagrożenia życia? Halina J ędrzejowska odpowiedziała: „Nie wiem. Nie umiem powiedzieć. Ale nie sądzę żeby to było możliwe”. 
Refleksyjność badacza nakazuje filtrować takie wspomnienia przez pryzmat czasu, który upłynął od wydarzeń. Czas może bowiem powodować idealizację przeszłości. Należy również pamiętać o tym, że większość konspiratorów, a następnie powstańców to ludzie młodzi, w wieku 20-30 lat, nie posiadający rodzin i dzieci, z poziomem brawury wyższym, niż u ludzi od nich starszych. Ze wspomnień weteranów II wojny światowej (a także żołnierzy badanych w ramach niniejszej pracy) wynika, że wiek i brak rodziny miał wpływ na podejmowanie działań niosących zwiększone zagrożenie dla własnego zdrowia i życia.

J eden z respondentów zwrócił uwagę na fakt, iż motywatorem do ryzykownego działania jest również chęć przeżycia czegoś wyjątkowego:

„W ich przypadku to był zwykły pragmatyzm. Byli wdanym miejscu i czasie, chcieli walczyć, więc znaleźli się w takim oddziale, bo chcieli robić coś wyjątkowego. J eśli mieli możliwość wyboru, wybierali jednostkę, która wiązała się z większym wysilkiem ryzykiem, ale też z dużo większą «zabawą». Zapotrzebowanie na adrenalinę tamtych ludzi było podobne jak u nas" (W5) ${ }^{4}$.

\section{Szacunek dla międzypokoleniowości}

Specyfika służby wojskowej powoduje relatywnie szybką fluktuację kadr w zespołach bojowych. Co roku z zespołu ubywa po kilka (niekiedy kilkanaście) procent personelu. Zastępują ich młodsi żołnierze. Należy więc założyć, że jeśli tożsamość grupy ma być długotrwała, trzeba zachowywać w pamięci i utrzymywać relacje międzyludzkie z osobami, które z grupy odeszły. Takie działanie ma na celu utrzymanie ciągłości grupy.

\footnotetext{
4 Tę opinię potwierdzają wspomnienia Cichociemnego, kpt. Zdzisława Straszyńskiego, który opowiadał autorowi, że polscy żołnierze, którzy podczas wojny znaleźli się w Wielkiej Brytanii, chcieli walczyć. Ale chcieli to robić w sposób spektakularny. Najwięcej chętnych było do służby w lotnictwie i marynarce wojennej. Jednostki lądowe uważane były za gorsze. Wyjątek stanowiły tworzone „nowoczesne” brygady - pancerna i spadochronowa. Etaty w nich były uważane za najbardziej elitarne.
} 
Autor określił to mianem „szacunku dla międzypokoleniowości” (definiując „pokolenie” jako to zbiór ludzi wmniej więcej podobnym wieku, mających podobne doświadczenia życiowe).

Relacje te objawiają się oczekiwanym przez jedną stronę zachowaniem drugiej strony: młodszych (służących w wojsku) - starszym (emerytom, weteranom, kombatantom), ale również odwrotnie(od starszych młodzi oczekują uznania z powodu specyficznych doświadczeń, które są obce poprzednim pokoleniom).

Na ile więc ważna jest tzw. łączność wojskowych pokoleń, wspólnota z patronami, poczucie dziedziczenia tradycji dla żołnierzy?

„Opowiem, jak dziedziczyliśmy tradycje batalionu «Miotła». Najpierw jeździliśmy na bardzo kurtuazyjne wizyty, trochę sztywne. (...) Ale jak kombatanci zaczęli opowiadać, jak i co robili, gdy mieli tyle lat co my, to począwszy od najmłodszego stopniem operatora po dowódcę zespołu, uświadomiliśmy sobie jak oni podobnie patrzyli na świat. Młodzi żołnierze mówią sobie: «No super, przeszedłem selekcję - jestem gość, przeszedłem szkolenie bazowe - jestem zajebisty, ale oni byli jeszcze bardziej zajebiści ode mnie». Żołnierze, zwłaszcza wjednostkach specjalnych, po przejściu pewnego etapu zyskują coś, co nazywam samozajebistością. Ale po zetknięciu z kombatantami pojawia się taki wewnętrzny głos: «Chłopaczku! Przed tobą jeszcze długa droga, tak naprawdę nie wieszjak zachowasz się w najtrudniejszej chwili. A tu stoisz przed osobą, która już się sprawdziła». Zaczyna się budowanie szacunku, pojawia się świadomość, że nie tylkoja robię niesamowite rzeczy, oni też takie robili" (W4).

„Mam kolegów, którzy byli na wojnie, odeszli z wojska i chwalą się teraz na «fejsie», gdzie byli. Tymczasem weterani są skromni, ich opowieści są niesamowite, ale nie ma tam żadnego wywyższania się (...) I my i oni walczyliśmy o Polskę. Trochę inaczej, bo oni na froncie bezpośrednio, a my gdzieś tam daleko. Alezawsze jest taki wspólny kierunek" (W6).

J eden z badanych wspominał organizowane w GROM-ie spotkania z Cichociemnymi:

„Dowódca bardzo zachęcał nas do czytania książek i spotkań z weteranami. To była dla nas woda na młyn. Poczytałeś, co oni robili, jak się szkolili, jak walczyli. 
A potem spotykasz się z nimi, a oni cię klepią po plecach. To nas inspirowało do tego, żeby być jeszcze lepszym, dorównać najlepszym. A oni byli najlepsi! Był z nimi wspólny język mimo, że oni byli starszymi, wiekowymi panami" (W3).

W roku 2014 jeden z Zespołów Bojowych J ednostki Wojskowej Komandosów zmienił tradycje. Zrezygnował z dziedzictwa Polskiego Samodzielnego Batalionu Specjalnego (PSBS), przejmując tradycje batalionu AK „Miotła”. Decyzja ta wzbudziła kontrowersje w środowisku Wojsk Specjalnych. Dla przeciwników zmiany były przykładem koniunkturalizmu, dla zwolenników - zbliżeniem żołnierzy do tradycji.

PSBS powstał w roku 1943 w ZSRR. J ego pierwszym dowódcą był mjr Henryk Toruńczyk, uczestnik wojny domowej w Hiszpanii. 4 września 1944 roku batalion przeszedł w podporządkowanie resortu bezpieczeństwa publicznego, połączono go z batalionem jeńców wojennych. Z tych jednostek powstał Korpus Bezpieczeństwa Wewnętrznego. Po zakończeniu II wojny światowej jego żołnierze walczyli z oddziałami antykomunistycznymi na Lubelszczyźnie i Podkarpaciu. Żołnierze PSBS obejmowali stanowiska w aparacie państwa i służb specjalnych, co doprowadziło do problemów z dostępem do dokumentów źródłowych. Natomiast popularna literatura przesycona jest mitologią i ideologizacją (Kister 2010).

Odnosząc się do tych kontrowersji, jeden z respondentów wyjaśniał: „Z mojej perspektywy wyglądało to tak. Młodzi ludzie w zespole mieli dylemat. Czy bohaterowie z PSBS są pozytywni, czy negatywni? To jest poważny dylemat dla człowieka, który poszukuje wzorców postepowania. Ja jako żołnierz mam szacunek dla ludzi z PSBS za to, co robili w czasie wojny. Byli żołnierzami rzuconymi na bardzo trudny odcinek. Oni walczyli o Polskę. Ale już po wojnie wykonywali zadania, które z mojej perspektywy nie są powodem do dumy. No więc był dylemat moralny. A w tym czasie pojawił się batalion „Miotła”. Tu nie mieliśmy dylematów" (W4).

Badany oficer stwierdził, że J ednostki Wojskowe Komandosów dziedziczyły wcześniej tradycje batalionów „Zośka” i „Parasol”, a „Miotła” w czasie Powstania Warszawskiego walczyła w tym samym zgrupowaniu 
„Radosław”. Stąd pojawił się pomysł na przejęcie tradycji również tego batalionu. Dowódca Zespołu Bojowego poinformował żołnierzy o pomyśle, przekazał im materiały na temat „Miotły” i dał dwa miesiące na zastanowienie. Po tym czasie przeprowadzono jawne głosowania:

„Ponad 80\% żołnierzy było za przejęciem nowych tradycji, pozostali nie czuli się związani z dotychczasową tradycją i było im wszystko jedno. Co ciekawe później, po spotkaniach z kombatantami, większość z tych $20 \%$ była bardziej zapalona, od początkowych zwolenników, bo dla nich było zaskoczenie, że tradycja może być czymś tak żywym" (W4).

Na decyzję o zmianie patrona wpływ miał również brak „szacunku dla międzypokoleniowości” ze strony byłych żołnierzy do obecnie służących.

„Po pierwszych Festynach Komandosa w Dziwnowie [Międzypokoleniowych spotkaniach komandosów - J.R.] trochę się rozjechaliśmy ze starszymi kolegami z Dziwnowa. Przyjeżdżaliśmy tam my - ludzie zjednostki nr 4101, z naszywkami PSBS na ramionach, dziedziczymy numer i symbolikę, a od swoich poprzedników słyszymy, że ci bardziej wolą odwoływać się do GROM-u. Dochodziło do takich sytuacji, że ci starzy żołnierze, którzy ćwiczyli tylko na poligonach mówili operatorom, którzy zaliczyli po kilka zmian w Iraku i Afganistanie: «A co ty tam wiesz o prawdziwym wojsku. To myśmy robili niesamowite rzeczy». Ci sami moi żołnierze jeździli na spotkania z kombatantami z «Miotły». Większa różnica wieku, alenie ma żadnych barier, licytowania się kto jest lepszy. Pełne zrozumienie, pełny szacunek, oni byli na wojnie, my byliśmy na wojnie. Wiemy co to jest ryzykowanie życia. Ale jeśli zmianę tradycji rozpatrywać to w kategoriach win, to wina jest po obu stronach" (W4).

Niechęć do starszych kolegów opisywał też kolejny badany:

„Ludzi z Dziwnowa nie darzę jakimś dobrym uczuciem. Kiedyś z nimi służyłem, ale oni trzymali się osobno, bo «byli z Dziwnowa». Teraz jeżdżą po naszych plecach, bo przecież to myśmy podnieśli tą jednostkę, dzięki nam zyskała trochę sławy. Oni opowiadają jakieś niestworzone historie z ćwiczeń, ale niech im będzie. To inne wojsko na inne czasy. My się z nimi nie dogadamy" (W6).

Przedstawiciele środowiska żołnierzy z Dziwnowa również zauważali problem. 
„Z perspektywy lat widzę, że łatwiej współczesnym specjalsom przyzwyczaić się do obecności starszych, niż starszym nauczyć się szacunku dla specjalsów. To jest rzecz, z którą od początku walczę. Nie można przez lata epatować słuchaczy swoimi jakimiś tam wyczynami z ćwiczeń. Że ktoś z nas «bombę» podłożył pod posterunek MO, ktoś tory rozkręcil. Ktoś kombajnem przyjechał na poligon, ktoś za księdza się przebrał. Tojest fajne do wspominania we własnym gronie. J ednak w zderzeniu z doświadczeniami młodego sierżanta po misjach takie historie budzą śmiech. Nie trzeba się przechwalać, ale mówić o wspólnych wartościach, podobnych elementach szkolenia. Myśmy ćwiczyli działania w terenie własnym zajętym przez przeciwnika, oni od kilku lat też to robią. Nasze doświadczenia mogą być cenne. J eśli znajdziemy nić porozumienia, to wtedy się pomieszczą dwie tożsamości: tego żołnierza po trzech zmianach w Iraku i tego, który przed kilkudziesięciu laty ćwiczył w Polsce" (W2).

Kolejny respondent skupił się na tradycji i tożsamości żołnierzy LWP. Aby podtrzymywać i rozwijać te wartości, przed ponad dekadą zaproponował - i od tego czasu organizuje - Festyn Komandosa. To spotkanie byłych i obecnych żołnierzy różnych jednostek specjalnych, ich rodzin oraz pasjonatów wojskowości. Odbywa się w sierpniu w Dziwnowie, w którym stacjonował 1. Batalion Szturmowy.

„Byliśmy bohaterami na tamten czas, do misji w Iraku i Afganistanie. Potem staliśmy się normalnymi byłymi żołnierzami. Ale to też ostrzeżenie dla dziś służących - może za kilkanaście lat oni też z pokorą będą musieli pochylić się nad działaniem następców.” Respondent przekonywał, że na łączności wojskowych pokoleń piętno wycisnęła bieżąca polityka: „Od niedawna tradycje wojskowe podzielono na dobre i złe. Ci z LWP reprezentują te złe tradycje. Ale ja uważam, że ci, który byli w LWP wnieśli coś do panteonu polskiej tradycji i polskich bohaterów" (W2).

Z rozmów z weteranami II wojny wynika, że świadomość, iż ktoś dziedziczy ich tradycje, ma dla nich znaczenie. Buduje prestiż, daje poczucie dumy, wyciąga z zapomnienia. Halina J ędrzejowska mówiła:

„Nam ten Lubliniec spadł jak z nieba. Nawet nie pamiętam, kto to wymyślił? Dzięki temu pamięć o «Miotle» odżyła. O «Parasolu» zawsze mówiło się dużo, o «Zośce» 
mówiło się dużo. A o nas cisza. (...) Ja się bardzo ucieszyłam, bo nasze tradycje mieli dziedziczyć komandosi, odważni, odpowiedzialni ludzie. Dziś już ich znam i byłoby mi obojętne jaką by formację reprezentowali, ale na początku to było ważne, że są komandosami. Oni przywrócili nam tożsamość".

J eśli relacje są rzeczywiste, na poziomie roboczym, stanowi to również ułatwienie w życiu codziennym. Halina J ędrzejowska tłumaczyła to na własnym przykładzie:

„Wielokrotnie było tak, że oni dzwonią i pytają czy czegoś nie potrzebujemy? Do końca życia nie zapomnę, jak zachorowałam i grupa z Lublińca przyjechała, żeby mnie odwiedzić w szpitalu, jak już byłam po operacji. Oni przez kilka godzin stali w moim pokoju oparci o ścianę, nie dostali kawy ani herbaty, rozmawiali opowiadali różne takie rzeczy, żeby mi nastrój poprawić. A wcześniej mi szpital wojskowy załatwili, żebym miała lepsze warunki".

Na podobieństwa, mimo różnicy wieku, wskazał jeden z badanych:

„Podobny stres i ryzyko. To jest niezmienne od wieków u ludzi, którzy muszą świadomie podejmować decyzje, narażając swoje życie i zdrowie w imię jakichś wyższych racji. Ta świadomość łączności nam pomaga. (...) To też taka transformacja tego, czego byśmy sami oczekiwali w przyszłości od naszych następców" (W5).

\section{Deformalizacja relacji}

Zasady dziedziczenia tradycji opisane są w dokumentach formalnych, na ich podstawie poszczególne oddziały i pododdziały podejmują szczegółowe działania dotyczące tego obszaru aktywności. Jednak część przedsięwzięć o charakterze wychowawczym, rytuałów i symboliki ma charakter nieformalny. Podejmują je ciała nieformalne, złożone z najbardziej doświadczonych żołnierzy zespołów bojowych, którzy tworzą tzw. „rady starszych” czy „kapituły zespołów”.

„U nas to była grupa najbardziej doświadczonych i najstarszych żołnierzy służących w poszczególnych sekcjach specjalnych zespołu. J ej członkowie mieli duże zaufanie kolegów i podwładnych. To byli podoficerowie - bo ich służy najwięcej 
wzespołach bojowych. Dowódca nie mógł się nie zgodzić na te kandydatury. Myśmy na początku wprowadzili taką zasadę, że każdy dowódca zespołu podpisuje się pod deklaracją, że zaakceptuje każdą tradycję zaproponowaną przez kapitułę, która będzie uświetniać etos zespołu, a nie będzie deprecjonować jego wartości" (W4).

Skład kapituły zależy od zasad ustalonych w poszczególnych zespołach. Członkami mogą być najstarsi stażem podoficerowie lub dowódcy pododdziałów lub najstarsi stażem przedstawiciele oficerów, podoficerów i szeregowych. Cechą wspólną jest fakt, iż jest to ciało nieformalne, pozostające poza strukturą organizacyjną.

„J ak sformalizujesz te rzeczy, to zgubisz sens. To wszystko jest pełne niuansów, próbowaliśmy to nawet jakoś formalizować, opisywać, ale zostaliśmy w szarej sferze, która dobrze funkcjonuje. Tego się nie da opisać w dokumentach. Bardzo ważna jest świadomość dowódcy, który musi wiedzieć jakie kwestie wymagają formalnego rozkazu, a kiedy trzeba pozwolić ludziom podejmować decyzje, może niekiedy wyglądające na nie najbardziej racjonalne, ale opierające się na intuicji i doświadczeniu" (W5).

Kapituła proponowała modyfikacje w programach szkolenia bojowego, współpracy między grupami, zespołami, a nawet jednostkami. Było to „Społeczne ciało doradcze” dowódcy, które może pełnić również funkcje wychowawcze. J eden z respondentów - członek kapituły - tłumaczył:

„Dowódcy łatwiej się dowodziło, jak miał kapitułę. Zlecał nam wprowadzanienowego człowieka, omówienie księgi zespołu, pokazanie jednostki. Czasem zlecał rozmowy wychowawcze. Do nas trafiała większość spraw dyscyplinarnych, którymi nie chcieliśmy zawracać dupy dowódcy. Myśmy to załatwiali we własnym gronie. Poszedł sobie chłop w mundurze na imprezę, popił, to decyzją kapituły odbieraliśmy mu prawo noszenia naszywki z «Miotłą» na pół roku. To była bolesna kara. J echaliśmy na poligon, każdy z «Miotłą», a on nie - jak te młodziaki zaraz po kursie bazowym. Słabo to wyglądało. Dowódca wiedział, że to działa więc zostawiał nam wolną rękę. To było nieformalne i było dobre. J ak sformalizujesz to nie wyjdzie, to nie może być wpisane w etat. Myśmy to robili dla nas i dla następców, żeby dbać o poziom zespołu" (W6). 
J ednym z najważniejszych zadań kapituły jest nadawanie odznak honorowych i tak zwanych coinów - monet pamiątkowych z symboliką oddziału, którą żołnierz wręcza jako wyraz uznania lub podziękowania.

Kolejny badany podkreślał, że kapituła to strażnik wartości oddziału: „Chodzi o trzymanie pieczy nad tym wszystkim, co najważniejsze. J est ryzyko, że - w czasie szybkiej wymiany kadr - przyjdą młodzi i zapomną, że to ważne. Żeby tego uniknąć młodych ludzi trzeba dobrze modelować, to rola starszych kolegów. Gorzej gdy starsi będą mieli na to wyjebane. Zdarzają się frustracje, konflikty w zespole więc różnie może być” (W7).

Rytualizacja i symbolika

Podobnie jak w innych, zhierarchizowanych, zamkniętych organizacjach o charakterze konserwatywnym - w Wojskach Specjalnych istotną rolę odgrywają rytuały i symbole. Część z nich jest niesformalizowana, ale w wybranych przypadkach będzie miała oddziaływanie silniejsze od czynników formalnych. Rytuały i symbolika nieformalna może być niezrozumiała, a nawet szokująca dla osób spoza środowiska.

Rytuałem jest święto jednostki specjalnej: część formalna (uroczystość) i nieformalna (spotkanie towarzyskie). J eden z respondentów podkreślał:

„To powinno być rozwijane i celebrowane. Fajna jest tradycja związana z Festynem Komandosa w Dziwnowie, organizowanym w okresie dawnego święta 1. Batalionu Szturmowego. Fajny event i super emocje mu towarzyszą. Każda okazja do spotkania jest dobra. Przez kilka lat byłem w USA i w Niemczech, tam żołnierze zbierają się z różnych okazji. J est nawet tradycja - według mnie niegłupia żeby raz w tygodniu spotkać się na piwie. Inaczej się ze sobą rozmawia, jak znamy się tylko służbowo, inaczej jak się napijemy piwa w miejscu neutralnym, porozmawiamy na inne tematy" (W7).

Istotną rolę odgrywa sala tradycji. Zgodnie z przepisami należy ją stworzyć w każdej jednostce wojskowej. Niektóre pododdziały tworzą własne izby. 
„To bardzo ważne. Przychodzi młody żołnierz, w sali siedzi kapituła, jest otwarta księga, czyta mu się podstawowe zasady, które u nas obowiązują. J akie ma prawa i obowiązki, nie służbowe, ale moralne. Może sobie zobaczyć pamiątki z misji czy poligonów. Zobaczyć pamiątki po kolegach, którzy zginęli” (W6).

Do rytuałów formalnych można zaliczyć - określone ceremoniałem wojskowym - uczestnictwo w uroczystościach związanych z dziedziczeniem tradycji (wydarzenia rocznicowe, pogrzeby) i odformalizowane (spotkania z weteranami: świąteczne, urodzinowe).

Istotne znaczenie integrujące mają rytuały nieformalne dotyczące awansów, obejmowania nowych funkcji, pozyskiwania nowych uprawnień, odejść ze służby, celebrowanie ślubów, narodzin dziecka. Zwykle jest to spotkanie w jednorodnym wojskowym środowisku, któremu towarzyszy spożywanie alkoholu.

„Wspólnie spożywany alkohol łamał hierarchię. Przy wódce byliśmy kolegami, a rano w jednostce wracała hierarchia. Ale to było bardzo ważne do budowy silnej grupy" (W2).

Żołnierze przekonywali, że wspólne spożycie alkoholu to nieodłączny rytuał wich służbie. Cytowali powiedzenie żołnierzy jednej z brytyjskich jednostek specjalnych, którzy mówili: „W pracy zap... na maksa, a po robocie nap... się na maksa".

Uzyskiwaniu nowych uprawnień służbowych również inne towarzyszyły rytuały. Po pierwszym skoku spadochronowym spadochroniarze uderzali nowicjusza deską po pośladkach.

„U nas na zakończenie kursu podstawowego delikwentowi zakładało się wór na głowę, w tym worze odpalało «cegiela» [CGŁ-1, ćwiczebny granat łzawiący - J.R.], w dupę strzelało z FX-a [amunicja ćwiczebna, wktórej pocisk wykonany jest z tworzywa sztucznego i wypelniony farbą - postrzelenie takim pociskiem powoduje dotkliwy ból i pozostawia ślad farby na mundurze - J.R.]. No i wszyscy się dobrze bawili poza tym, który miał ten wór na głowiei dostał w dupę. Dla niektórych kończyło się źle, bo musiał spędzić parę dni w szpitalu, bo dawka była naprawdę jak dla konia. Trochę głupie, ale tak było. Amerykanie mają odznakę spadochronową. W czasie nadawania trzeba w nią walnąć tak, żeby metalowe zapięcia wbily się 
w klatkę piersiową. Ale w siłach specjalnych tak się bawią, nikogo to nie szokuje, taka tradycja" (W3).

Rytuałem jest nadawanie odznak. Zgodnie z przepisami dotyczącymi umundurowania na mundurze wyjściowym żołnierz musi nosić odznaki wyróżniające. O prawie do noszenia odznaki na mundurze polowym decydowała kapituła.

„Na mundurze wyjściowym młodzi nosili «Miotłę» zgodnie z prawem, ale bez prawa moralnego. Wojsko jest oparte na symbolach. Najlepiej to widać, jak ludzie traktują symbole oddziału. Pamiętam jak to wyglądało, gdy dziedziczyliśmy tradycje PSBS i jak było przy «Miotle». Z «Miotłą» żołnierze się identyfikowali» (W4).

„Właściwie takie poważne myślenie o tradycji zaczęło się po przejęciu tradycji «Miotły». Zaczęło się od księgi pamiątkowej. Tam wpisywaliśmy prawa i obowiązki żołnierza, zdjęcia i opisy z ważniejszych wydarzeń. Potem pojawił się pomysł na coina zespołowego. Wymyśliliśmy, że każdy żołnierz będzie dostawał numerowaną monetę. Najniższe numery mieli mieć ludzie o najdłuższym stażu. Ale kolega się zdenerwował, bo na zespół przyszedł jako doświadczony żołnierz, a numer miał mieć wyższy od młodszych, którzy dłużej byli w zespole. Powiedział, że on takiego coina nie chce. No i zrobiliśmy listę z datami przyjścia do wojska. Dużo było dyskusji i przeliczeń, bo jak najniższy numer to była sprawa honorowa" (W6).

Oprócz indywidualnych, numerowanych coinów dla żołnierzy pododdziału wybija się także coiny honorowe ( $\mathrm{z}$ literą „H” w miejscu numeru) oraz coiny nienumerowane, które żołnierze mogli zamawiać na własny koszt i wręczać według uznania.

Prawo do noszenia odznaki na mundurze polowym młody żołnierz otrzymywał po określonym czasie nienagannej służby (najczęściej roku). Prawo do wręczenia coina otrzymywał po roku lub dwóch latach wzorowej służby. Respondenci tak to wyjaśniali:

„Młody formalnie był wjednostce, ale musiał popracować, żeby zarobić na «Miotłę» (W6). 
„Pilnowaliśmy tych dat, bo to było związane z takim rytuałem przejścia. Ustalaliśmy z pozostałymi «starymi knurami» z kapituły, ze to już jest ten moment, że «młodemu się należy». W czasienormalnej zbiórki załatwiało się typowe sprawy, pojawiła się sprawa naszywek: «kto zamawia i ile naszywek?» Kto chciał kupić, to się zgłaszal. «Młody, a ty coś zamawiasz? Bo już możesz zamówić». Tak to wyglądało" (W5).

W pierwszych latach istnienia GROM-u rytuały dotyczące nadawania odznak i innych wyróżnień były rozbudowane bardziej, niż w innych jednostkach specjalnych.

„Wręczano je w czasie ważnych uroczystości. Był gość specjalny, jakiś minister, Cichociemni, goście z SAS czy Delty. Dowódca prosił najważniejszego gościa o wręczenie wyróżnienia. Zawsze miało to wyglądać podniośle. Dostać naszywkę czy dyplom od Cichociemnego - to było «łał», to się pamięta do końca życia. Petelicki bardzo dbał o podniosłość takich wydarzeń, inni dowódcy może trochę mniej. Dbał, żeby były fajne zdjęcia z takiej uroczystości. Dostawaliśmy pamiątki na całe życie" (W3).

Identyfikacja wizualna: symbolika, odznaki, rytuały mogą wynikać bezpośrednio z tradycji historycznej, ale mogą również „nabrać własnego życia” i funkcjonować jako element wyróżniający, którego kultywujący tradycje nie identyfikują historycznie.

„Z czym się identyfikowałem? Choćby z naszywką, symbolem. Myśmy je nosili na ramieniu. W każdym miejscu, gdzie pojechaliśmy, tam «Miotta* na ramieniu była. (...) Różnie młode chłopaki podchodziły do spraw tradycji i historii. Ale wszyscy bardzo czekali na ten moment, żeby po roku służby na zespole mieć prawo do noszenia «Miotty» na ramieniu. To pozwalało im wejść w zamknięty krąg zespołu" (W6).

Czy ma sens budowanie tradycji i silnej tożsamości wokół grupy, która - co wynika z pragmatyki służby wojskowej - nie jest stała? W wojsku obowiązuje kadencyjność oraz przypisanie stopnia do stanowiska. Awans najczęściej oznaczał przejście na inne stanowisko w macierzystej lub nowej jednostce wojskowej. 
„Ale tak to funkcjonuje na świecie. Pewną tożsamość masz w danej grupie, zmieniasz grupę i zmieniasz tożsamość. Ale najważniejsze wartości są bez zmian. ODY 555 i 554 [ODA - Operational Detachment Alpha - najmniejszy, zwykle 12-osobowy, pododdział Zielonych Beretów, jednostek specjalnych US Army J .R.] w roku 2001 jako pierwsze lądowały w Afganistanie. Ludzie, którzy wtedy je tworzyli już dawno są emerytami, numery pozmieniano w czasie reorganizacji. Ale zostały historia i legenda. Do dziś jak się o nich mówi to na zasadzie: «Aha! To ci, którzy byli pierwsi w Afganistanie». Formalnie ze starą formacją łączą ich tylko koszary, w których stacjonują od dekad, ale tradycja jest żywa” (W5).

Elitarność oddziałów specjalnych wzbudza zainteresowanie tymi formacjami. Publikacje w mass mediach oddziałują na wyobraźnię osób, które chcą się wzorować na żołnierzach. To skutkuje przenikaniem tradycji i symboliki oddziałów Wojsk Specjalnych do popkultury. W handlu ogólnodostępne są koszulki i gadżety z symboliką współczesnych i historycznych jednostek specjalnych oraz same odznaki tych jednostek. Tojest klasyczny przykład komercjalizacji tradycji wytworzonej.

„To jest po prostu biznes. Zawsze znajdą się ludzie, którzy na elitarności chcą zarobić. Po tym jak pojawiło się kilka artykułów o pierwszych sukcesach Lublińca w Afganistanie, gwałtownie wzrosła liczna gadżetów z logo JWK. To powinno być regulowane, znakjest bardzo często deprecjonowany" (W4).

„Zawsze podaję przykład Stadionu Narodowego. Jeśli ktoś komercyjnie, bez zgody, wykorzysta zdjęcie stadionu to naraża się na kilkadziesiąt tysięcy złotych kary. A «Gromiki» nosi każdy. Przecież jednostka ma dział prawny, gdyby na stronie internetowej pojawiła się informacja, że grożą kary za nieprawidłowo czy nielegalnie użyty znak, to by można ukrócić ten proceder. GROM to marka rozpoznawalna na świecie, a nikt nie chroni jej znaku towarowego" (W3).

Żołnierze uważają, że nie byłoby nic złego w przenikaniu się popkultury z symboliką, gdyby ustalono zasady wykorzystania tej symboliki. Wtedy służyłoby to promocji Wojsk Specjalnych.

„A terazjest tak, że znak Polski Walczącej wykorzystują środowiska skrajnej prawicy czy kibole. To nie powinno mieć miejsca, bo uwłacza symbolowi. Z drugiej 
strony środowiska lewackie wykorzystują takie sytuacje do uderzenia w wojsko czy państwo" (W7).

Analiza obszarów mogących mieć kluczowe znaczenie dla budowy tożsamości żołnierzy oddziałów specjalnych uprawnia do wysnucia wniosku, iż silne poczucie tożsamości żołnierzy oddziałów Wojsk Specjalnych ułatwia realizację stawianych im zadań.

„Natomiast tradycja nie istnieje sama dla siebie, ale dla osiągnięcia pewnego celu. Poczucie przynależności do grupy ułatwia służbę, a tradycja jest kręgosłupem moralnym. Połączenie tych dwóch rzeczy daje pozytywny efekt” (W4).

Tradycja może być oparta na historii wojskowości, ale równie atrakcyjna dla żołnierzy może być tradycja oparta na innych parametrach. Respondenci uważają, że nigdy nie uda się we wszystkich żołnierzach oddziału zbudować tak samo wysokiego przywiązania do tradycji.

Poczucie elitarności i silnej tożsamości stymuluje żołnierzy, jednak elitarność należy sprawdzić w praktyce. J eśli tego zabraknie, wśród żołnierzy może rodzić się poczucie frustracji.

„Nowy sprzęt, intensywny trening, pochwały - to kręci. Tylko to może kręcić przez 2-3 lata. Potem trzeba gdzieś pojechać na misję i się sprawdzić. Po pięciu latach bez wyjazdów to się staje nudne, przyjeżdża kolejny polityk i mówi: «Jesteście najlepsi, super». A my wiemy, że niewiele zrobiliśmy. Musimy się sprawdzić w realu, bez tego będzie tylko narastać irytacja" (W3).

Wiedza o dziedziczonej tradycji może ułatwiać służbę.

„My inaczej pracujemy, planowanie zadania trwa dłuższy czas. «Miotlarze» jak się dowiedzieli, że cel jest na miejscu, to się zbierali, robili szybką odprawkę i szli. To wymagało większej odwagi. Oni cały czas pracowali na najwyższych obrotach. My mamy czas między misjami, odpoczywamy sobie, oni cały czas pozostawali w zagrożeniu. Wiem jak ja się czuję na wyjeździe. W bazie można trochę odsapnąć, na robocie jest maksymalne skupienie. Ale u nas to jest na chwilę, na parę miesięcy. Oni cały czas tak żyli. To daje takie poczucie, że my na misjach mamy ciężko, ale oni wytrzymali zdecydowanie więcej, więc i my damy radę" (W6). „Ułatwiała służbę za granicą. Siedzisz z ludźmi zjednostki, która «odpaliła» Bin Ladena. Oni są napompowani dumą, a ty im opowiadasz o akcji na Kutscherę. I oni 
mówią: «Łał. To się dało zrobić w kilku ludzi na terenie całkowicie opanowanym przez przeciwnika?» No i jest fajnie, bo ich zaskoczyłeś, pokazałeś, że nie są największymi kozakami na świecie, bo nasi 70. lat temu nie takie rzeczy robili” (W3). „U Brytyjczyków czy Amerykanów tradycje są bardzo ważne, ale są eksponowane w odpowiednich momentach. Nie chodzi o to, żeby historia przesłaniała nam rzeczywistość, żeby przy najdrobniejszych rzeczach się do niej odwoływać” (w5). Należy domniemywać, że odwołanie do tradycji historycznych daje żołnierzom dodatkowo poczucie ekskluzywności. Jest jak pochodzenie społeczne - posiadanie pokoleń przodków wywodzących się z wyższych klas społecznych. Wydaje się to być szczególnie istotne w sytuacjach nowych, przebywania w obcym środowisku, w którym kod kulturowy własnej, zamkniętej grupy może być niezrozumiały. J eden z badanych podał przykład żołnierzy amerykańskich, których spotkał w Afganistanie:

„Oni poczytali sobie w Internecie o wyprawach krzyżowych. Zaczęli sobie przypisywać tradycje rycerzy średniowiecznych. Na jednej zmianie trafił mi się żołnierz, który z dumą nosił naszywkę Zakonu Krzyżackiego. Myśmy mu wytłumaczyli, że to trochę słabo odwoływać się do takiej przeszłości. I on mówi: «No jak to? To oni nie byli tacy zajebiści?» Od nas dowiedział się, nie. I żołnierz zdjął naszywkę Krzyżaków. Daliśmy mu naszywkę «Miotły» - też ją z dumą nosił. Musi być odwołanie do tradycji, bo ludzie szukając korzeni będą jak ten żołnierz amerykański" (W4).

Skoro poczucie tożsamości związanej ze służbą wojskową może ułatwiać wykonywanie zadań, to czy może również kształtować postawę moralną żołnierzy? Opinie respondentów nie były jednoznaczne.

„Powinno, ale bym tego nie przeceniał. Możemy obserwować, co się dzieje w USA. Są sprawy sądowe o zbrodnie wojenne, gwalty, morderstwa pedofilie, handel narkotykami. Wszystko to dotyczy ludzi wyselekcjonowanych, z jednostek specjalnych. (..) Trudno wymagać od człowieka szkolonego do zabijania innych, żeby miał mentalność wikarego z małej parafii. Ci ludzie muszą operować winnych granicach moralności. Definicje tego, cojest przyzwoite, a co nie, cojest dopuszczalne, a co nie, są inne. Ale też nie można takich ludzi zastawiać samym sobie, żeby samodzielnie definiowali te kwestie" (W5). 
„Wojsko jest systemem, który modeluje człowieka, nie tylko pod kątem związanym z celami, ale też jakim się jest człowiekiem. Wartości moralne nie idą w tym samym kierunku co zadania, które czasami żołnierz ma do wykonania. Tu może być konflikt interesów" (W7).

„Po to się to robi, żeby dawać drogowskaz, linię moralną. J ak przejmowaliśmy tradycje «Miotły», to chłopaki wyczytali, że oni byli zajebiści, bo wykonywali wyroki śmierci na kolaborantach. No i stało się coś, co z mojego punktu widzenia było niekorzystne, żołnierze się bardzo skoncentrowali na tym, że «Miotlarze» «odpalali» kolaborantów. Spodziewali się, że usłyszą jakieś niesamowite historie na ten temat. A tu się okazało, że nie. Oni mieli olbrzymie dylematy moralne, bo musieli likwidować Polaków, choć działali na podstawie wyroków podziemnych sądów. No i chłopaki z zespołu już całkiem inaczej zaczęli patrzeć na zadania związane zlikwidacją ludzi, właśnie przez pryzmat doświadczeń «Miotlarzy»” (W4).

Respondenci zostali zapytani o to, czy odniesienia do tradycji historycznej (do sprawy poświęcenia zdrowia czy życia przez patronów) uławiają służbę w sytuacjach trudnych (śmierć żołnierzy, odniesienie obrażeń przez kolegów)? Żaden z respondentów nie potwierdził takiej tezy.

„Ciężko powiedzieć, wtedy to już bardziej istotne chyba będą więzi wewnętrzne.

Wtedy główne role odrywa zgranie zespołu, więzi między ludźmi” (W4).

J eden z respondentów, żołnierz pododdziałów bojowych i jeden z najbardziej doświadczonych polskich ratowników medycznych sił specjalnych, podsumował:

„Mam takie zdjęcie operatora sił specjalnych USA. Leży w łóżku szpitalnym, ma amputowane obie nogi, jest mocno pokiereszowany, ale na głowie ma zielony beret. Widać, że on nie jest złamany, więc z psychologicznego punktu widzenia te elementy budujące postawę moralną są jak najbardziej istotne. Oczywiścienie można powiedzieć, że każdy mający w głowie silne przywiązani do tradycji, silne poczucie tożsamości, się nie załamie w bardzo trudnej sytuacji, ale wydaje mi się, że te aspekty mogą być bardzo pomocne w sytuacjach kryzysowych” (W7). 


\section{Podsumowanie}

Należy stwierdzić, iż tradycje oddziałów historycznych dziedziczone przez formacje specjalne ułatwiają budowanie tożsamości współczesnych żołnierzy WS. J est tojednak tylkojeden zelementów procesu. J ak wynika z przeprowadzonych badań, dla większości żołnierzy nie jest to element najważniejszy.

Tradycja odgrywa istotną rolę w procesie budowania tożsamości, nie należy jej jednak traktować wyłącznie (choć tak jest postrzegana zarówno przez opinię publiczną, jak i decydentów) jako odniesienie do historii wojskowości:

1. Tradycjajest dla żołnierzy WS spoiwem, wokół którego budują tożsamość własną oraz własnych oddziałów. Odniesienia do tradycji historycznych dają żołnierzom poczucie „szlacheckości” i wzmacniają „wojskowy kręgosłup”. Tradycji nie należy jednak odnosić wyłącznie do historii wojskowości. Respondenci traktują ją o wiele szerzej, za „tradycyjne” uznając zwyczaje i symbole (zastanei/lub wypracowane przez nich samych lub środowisko) w ciągu ostatnich kilku czy kilkunastu lat.

2. Tradycja pozwala na emocjonalną łączność z poprzednimi pokoleniami żołnierzy i daje poczucie przynależności do elitarnej grupy. J ednak ze względu na specyfikę służby i wynikającą z niej fluktuację kadr, określenie „pokolenie” należy definiować jako zbiór żołnierzy mających podobne doświadczenia wojskowe. Łączność z poprzednimi pokoleniami pomaga żołnierzom w prawidłowej ocenie własnych możliwości i osiągnieć.

3. Pomimo głębokich przemian społecznych, będących efektem późnej nowoczesności, wojsko jest organizacją konserwatywną, dlatego nawiązywanie do tradycji nadal ma znaczenie dla oddziałów WS. Żołnierze to osoby o poglądach konserwatywnych w sferze ideologii (pozytywnie odnoszący się do idei 
silnej roli państwa, szacunku dla tradycji narodowej - nie należy tego jednak wiązać z konkretnymi ruchali politycznymi) oraz obyczajowości (tolerancja dla różności tożsamości seksualnych połączona z brakiem akceptacji dla ekspansywności środowisk promujących odmienne tożsamości). Stosunek żołnierza do tradycji zależy od jego wychowania (w rodzinie, środowisku) oraz poziomu akceptacji działań dotyczących tradycji podejmowanych przez oddział, w którym żołnierz służy.

4. Wojskowe jednostki specjalne z okresu 1951-1989 nie odnosiły się, lub odnosiły się w sposób mocno sformalizowany do tradycji, a mimo to posiadały bardzo mocną tożsamość. Wśród żołnierzy może ona przetrwać dekady po zakończeniu służby wojskowej.

5. Tradycjemożna wykorzystywać w procesach budowyi utrwalania tożsamości oddziałów WS, a nawet (co potwierdza przykład Festynu Komandosa) utrwalania tożsamości byłych żołnierzy. Aby w skali masowej był to proces skuteczny, przekaz dotyczący tradycji musi być jednoznaczny (podobnie jak w przekazie tabloidowym: biały lub czarny, bez skali szarości) i uproszczony (bez niuansowania, z prostym przekazem dotyczącym najważniejszych wydarzeń historycznych oraz z nieodległych kilku, kilkunastoletnich - zdarzeń istotnych dla oddziału). Przekaz musi być atrakcyjny i bliski żołnierzom. Nie może więc być wyłącznie elementem obowiązkowego szkolenia wychowawczego, musi angażować emocjonalnie i prezentować zagadnienia w sposób, który żołnierze uznają za tożsamy z własnymi poglądami i wartościami.

6. Tożsamość historyczna ma wpływ na przebieg służby żołnierzy WS, podkreśla elitarność tego rodzaju Sił Zbrojnych, daje więc dodatkową motywację do wysiłku w czasie szkolenia i poświęcenia podczas działań bojowych. 
Po analizie wypowiedzi respondentów należy domniemywać, że bez wytworzenia poczucia tożsamości w oddziale nie będzie on mógł optymalnie prowadzić pełnego spektrum operacji specjalnych. W efekcie analizy przeprowadzonych wywiadów autor niejest jednak w staniejednoznacznie odpowiedzieć na pytanie, czy poczucie tożsamości może również kształtować postawę moralną żołnierzy? Respondenci wskazywali bowiem, że specyfika zadań stawianych przed żołnierzami WS może być sprzeczna ze społecznym poczuciem moralności.

Warta podkreślenia jest również opinia respondentów zapytanych o to, czy odniesienia do tradycji historycznej uławiają służbę w sytuacjach trudnych (śmierć, odniesienie obrażeń przez kolegów)? Żaden nie potwierdził takiej zależności. Większą rolę w takich sytuacjach odgrywać będzie poczucie tożsamości grupy, a nie odniesienia do historii.

\section{Literatura}

Cannadine, D. (2008) Kontekst, celebracja i znaczenie rytuału: monarchia brytyjska $i$ „wynajdywanie tradycji” w latach 1820-1977. [w:] Tradycja wynaleziona. (red.) Hobsbawm, E., Ranger, T. Kraków: Wydawnictwo Uniwersytetu Jagiellońskiego.

Hobsbawm, E. (2008) Wprowadzenie. Wynajdywanie tradycji. [w:] Tradycja wynaleziona. (red.) Hobsbawm, E., Ranger, T. Kraków: Wydawnictwo Uniwersytetu J agiellońskiego.

Kister, A.G. (2010) Pretorianie, Polski Samodzielny Batalion Specjalny i Wojska Wewnętrzne 18 X 1943-26 III 1945. Warszawa: Instytut Pamięci Narodowej.

Markert, A.E. (2004). Gloria Victis. Tradycje powstania styczniowego $w$ drugiej Rzeczpospolitej. Pruszków: Ajaks.

Napiórkowski, M. (2016). Powstanie umartych. Historia pamięci 19442014. Warszawa: Krytyka Polityczna. 
Pawlina, S. (2016). Praca $w$ dywersji. Codzienność żotnierzy Kedywu Okręgu Warszawskiego Armii Krajowej. Gdańsk: Muzeum II Wojny Światowej.

Roper, H.T. (2008) Góralska tradycja Szkocji. [w:] Tradycja wynaleziona. (red.) Hobsbawm, E., Ranger, T. Kraków: Wydawnictwo Uniwersytetu J agiellońskiego.

Sińczuch, M., Zauer, J . (2015). Świadomość historyczna oraz poczucie patriotyzmu wśród żolnierzy zawodowych. Sprawozdanie z badań. Warszawa: Wojskowe Centrum Edukacji Obywatelskiej.

Stachiewicz, P. (1981). „Parasol”. Dzieje oddziału do zadań specjalnych Kierownictwa Dywersji KG AK. Warszawa: Instytut Wydawniczy PAX.

Szacki, J . (1971). Tradycja. Warszawa: PWN.

Tymieniecki, B. (1997). Na imię jej było Lily. Warszawa: Wydawnictwo MON.

Wiatr, J . (1983). Socjologia wojska. Warszawa: Wydawnictwo MON.

Zauer, J. (2018). Patriotyzm i świadomość historyczna żotnierzy Sit Zbrojnych RP. Sprawozdanie z badań. Warszawa: Wojskowe Centrum Edukacji Obywatelskiej.

Zauer, J. (2017). Świadomość historyczna, poczucie patriotyzmu, edukacja obywatelska i proobronna w Siłach Zbrojnych RP. Sprawozdanie z badań. Warszawa: Wojskowe Centrum Edukacji Obywatelskiej. 